\title{
Redescription of Apostolepis ambiniger (Peters, 1869) (Serpentes: Dipsadidae: Elapomorphini)
}

\author{
Omar M. Entiauspe-Neto ${ }^{1}$, Claudia Koch ${ }^{2}$, Michael B. Harvey ${ }^{3}$, \\ Guarino R. Colli ${ }^{4}$, Thaís B. Guedes ${ }^{5,6}$ \\ 1 Universidade Federal do Rio Grande, Instituto de Ciências Biológicas, Laboratório de Vertebrados, Av. Itália Km 8, CEP: 96203-900, Vila \\ Carreiros, Rio Grande, RS, Brazil \\ 2 Zoologisches Forschungsmuseum Alexander Koenig, Adenaueralle 160, 53113 Bonn, Germany \\ 3 Department of Biological Sciences, Broward College, 3501 Southwest Davie Road, Davie, FL 33314, USA \\ 4 Departamento de Zoologia, Universidade de Brasília, 70910-900, Brasília, DF, Brazil \\ 5 Universidade Estadual do Maranhão, Centro de Estudos Superiores de Caxias, Programa de Pós-Graduação em Biodiversidade, Ambiente e \\ Saúde, Praça Duque de Caxias, 65604-380, Caxias, MA, Brazil \\ 6 University of Gothenburg, Gothenburg Global Biodiversity Center, Department of Biological and Environmental Sciences, Box 461 , 40530 \\ Göteborg, Sweden
}

http://zoobank.org/E3969D3B-48CE-4760-8FF9-A65E19A09AD6

Corresponding author: Thaís B. Guedes (thaisbguedes@yahoo.com.br)

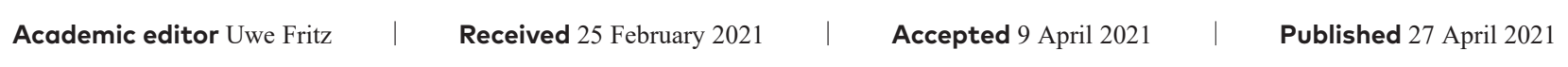

Citation: Entiauspe-Neto OM, Koch C, Harvey MB, Colli GR, Guedes TB (2021) Redescription of Apostolepis ambiniger (Peters, 1869) (Serpentes: Dipsadidae: Elapomorphini). Vertebrate Zoology 71: 231-251. https://doi.org/10.3897/vz.71.e65097

\section{Abstract}

Apostolepis is a diverse genus of dipsadid snakes, currently comprising 34 species occurring in most cis-Andean South America. The taxonomy of the group is highly unstable. Upon discovering its type series, we redescribe the rare species A. ambiniger (Peters, 1869) and provide an account of its geographic distribution and morphological variation in pholidosis, osteology, and hemipenial characters. We also discuss some aspects of the taxonomy of Apostolepis.

\section{Keywords}

Geographic distribution, micro-CT, morphology, Neotropical, osteology, Squamata, taxonomy.

\section{Introduction}

The tribe Elapomorphini contains approximately 50 species of fossorial and cryptozoic snakes, widely distributed across cis-Andean South America (Ferrarezzi 1993; Harvey 1999; Entiauspe-Neto et al. 2019, 2020a). The tribe contains five genera: Apostolepis Cope, 1861, Coronelaps Lema and Hofstadler-Deiques, 2010, Elapomorphus Wiegmann (in Fitzinger), 1843, Parapostolepis Amaral, 1930, and Phalotris Cope, 1862. These genera share the follow- ing diagnostic characters: nasal plate undivided, frontoparietal suture U-shaped, dentigerous process of the dentary short, frontal bones dorsally included by the anterolateral process of the parietal, supralabial scales few (5-7), and second supralabial contacting the eye (Savitzky 1979; Ferrarezzi 1993, 1994; Zaher 1994; Zaher et al. 2009).

The genera of Elapomorphini can usually be differentiated from one another by scalation and coloration features, 
which show varying degrees of reduction associated with fossorial and cryptozoic habits (Lema 2001; Ferrarezzi 1993). Apostolepis bears a pair of prefrontals (possibly) fused to internasals, 15 dorsals, and a black tail tip (except for A. quinquelineata); Parapostolepis bears a black tail tip and has 17 dorsals; Phalotris has a single prefrontal plate, separated from the internasals; Coronelaps and Elapomorphus have paired internasals and prefrontals. Osteological and hemipenial characters further distinguish these last two genera (Ferrarezzi 1993; Lema 2001; Lema and Hofstadler-Deiques 2010).

Apostolepis is the most diverse of the elapomorphine genera, with 34 species occurring in open and forested biomes from southern Colombia and the Guyana Shield to southern Brazil and northern Argentina (Ferrarezzi 1993; Entiauspe-Neto et al. 2019, 2020a, 2021). Specimens of Apostolepis are usually poorly represented in collections, and several species are known from fewer than ten specimens (Harvey 1999; Nogueira et al. 2012). Their apparent rarity has contributed to great taxonomic instability, as many species were first described based on a single or very few specimens, only to be first synonymized and then revalidated (Entiauspe-Neto et al. 2019, 2020a, b).

Like many congeners, Apostolepis ambiniger (Peters, 1869) has an interesting and complicated taxonomic history. It was described as Rhynchonyx ambiniger, a new genus and species, based on a single specimen "Bought; allegedly from Paraguay" ("Gekauft; angeblich aus Paraguay") (Peters 1869); the description includes remarks on body shape, pholidosis, coloration, and morphometry. Cope (1887) described $R$. ambiniger vittatus based on a specimen with longitudinal dark-brown bands, collected during the Naturalist Brazilian Exploring Expedition by H. H. Smith at or near "the village of Chupada" (= Chapada dos Guimarães), Mato Grosso, Brazil. Peracca (1895) studied specimens collected by the Franco-Italian zoologist Alfredo Borelli during his voyage to the South American Chaco and listed one specimen of Elapomorphus erythronotus (currently Apostolepis dimidiata [Jan, 1862]) from Asunción, Paraguay. Boulenger (1896) synonymized Rhynchonyx with Apostolepis, redescribed $A$. ambiniger, and emended its specific epithet to ambinigra. Further, Boulenger (1896) placed Elapomorphus erythronotus Peracca and $R$. ambiniger vittatus in the synonymy of $A$. ambiniger. Earlier, Boulenger (1894) had identified specimens collected by J. Bohls in Asunción, Paraguay, as Apostolepis dorbignyi (Schlegel, 1837), but later assigned them to A. ambiniger (Boulenger, 1896).

Koslowsly (1898) mentioned the presence of Apostolepis ambiniger in Brazil, based on specimens collected by C. Bach in Miranda, Mato Grosso do Sul. Unfortunately, all specimens collected by Julio G. Koswlosly, deposited at Museo La Plata, are presumably missing (Thales de Lema, personal communication). Amaral (1929) synonymized Apostolepis tenuis Ruthven, 1927 with $A$. ambiniger, considering it was "too close to Rhynchonyx ambiniger vittatus to merit place in systematics" ("proxima demais de $A$. ambinigra vittata (Cope), para merecer logar em systematica"). Hartweg (1932) revalidated $A$. tenuis based on comparing its type specimen with two specimens of $A$. ambiniger (UMMZ 67962, 67963 ) housed at the UMMZ. Peters and Orejas-Miranda (1970) considered Boulenger's emendation (Boulenger 1898) unjustified and retained the original spelling ambiniger, and maintained $A$. tenuis in the synonymy of $A$. ambiniger because they missed the paper by Hartweg. Shortly after, Peters and Orejas-Miranda (1972) rejected the synonymy of either $A$. tenuis or $A$. vittatus with $A$. ambiniger and provided morphological data on an additional specimen of $A$. ambiniger from Argentina. Harvey et al. (2001) reported new specimens of $A$. ambiniger from Paraguay, and Lema et al. (2005) provided an account of morphological variation while also mentioning that the type specimen was missing.

A great deal of this twisty taxonomic history is due to the limited number of specimens at hand in previous studies. This condition limited a proper assessment of intraspecific variation and robust species delimitation through comparisons with congeneric species. Recently, we found the type specimen of Apostolepis ambiniger. Here we redescribe $A$. ambiniger, report morphological variation, and describe the skull and hemipenis to promote stabilization in this group's taxonomy. We also present comparisons between congeners and comments on the taxonomy of Apostolepis.

\section{Material and Methods}

We examined a total of 697 specimens of Apostolepis (Appendix 1). Throughout this paper, we use the museum acronyms of Sabaj (2019). Scale counts follow Dowling (1951) and Peters (1964). Sex determination was done with a ventral incision in the base of the tail. An emended diagnosis is based on the nomenclature used by Entiauspe-Neto et al. (2020a). We measured head length (from the center of the rostral to the corner of mouth) and head width (at the corner of mouth) to the nearest $0.01 \mathrm{~mm}$ using a dial caliper; snout-vent length (SVL, from the center of the rostral to the posterior margin of the cloacal scale) and tail length (from the posterior margin of the cloacal scale to the distal tip of the terminal scale) to the nearest $1 \mathrm{~mm}$ using a flexible ruler. We measured scales on the right side of head and define our measurement within the description when appropriate. We used the PAST 4.03 statistical software program (Hammer et al. 2001) for all statistical tests. To investigate relative tail length, we used analysis of covariance (ANCOVA), treating SVL as a covariate. For the ANCOVA, we verified the assumption of parallel slopes with an $F$-test. To test for sexual dimorphism in segmental counts, we used a $t$-test after first verifying assumptions of homogeneity of variance (using an $F$-test) and normality (using the Shapiro-Wilk test). When describing sexual dimorphism, we report ranges followed in parentheses by mean \pm 1 standard deviation and sample size. For statistics, we provide samples of each group as subscripts. 
We describe osteology of the skull of the holotype of A. ambiniger (ZMB 6450) based on a high-resolution micro-CT scan, performed with a Bruker SkyScan 1173 at the ZFMK. The scan used an X-ray beam with $43 \mathrm{kV}$ source voltage and $114 \mu \mathrm{A}$ current without the use of a filter. Rotation steps of $0.3^{\circ}$ degrees were used with a frame averaging of 5 , recorded over a $180^{\circ}$ rotation, resulting in 800 projections of $500 \mathrm{~ms}$ exposure time each, and a total scan duration of $47 \mathrm{~min} 12 \mathrm{~s}$. The magnification setup generated data with an isotropic voxel size of $8.16 \mu \mathrm{m}$. We reconstructed the CT-dataset using N-Recon software version 1.7.1.6 (Bruker MicroCT) and rendered an image in three dimensions through the aid of Amira visualization software (FEI, Thermo Fisher Scientific). Segmentation to separate and color the bones was also performed using Amira. For the description of the skull, we use the osteological terminology of Bullock and Tanner (1966) and Cundall and Irish (2008), and the description of the skull follows Entiauspe-Neto et al. (2020a, 2021). We compared the skull of $A$. ambiniger to descriptions of the skulls of $A$. assimilis, $A$. cearensis, and $A$. sanctaeritae (Ferrarezzi et al. 2005; Entiauspe-Neto et al. 2021).

We used the verified point record database of $A$. ambiniger (Table 1 in the Supplementary Table) to draw the map of its distribution and calculate its extension of occurrence (EOO) by using QGIS version 3.16 (QGIS Development Team 2021).

\section{Results}

\section{Nomenclatural Remarks}

According to the International Code of Zoological Nomenclature (ICZN 1999, hereafter referred to as the Code), a species name (should it be in Latin, or a nominative singular particle or adjective after latinization) should agree in its gender with the generic name of its combination (Art. 31.2). Previously, we mentioned that Peters and Orejas-Miranda (1970) considered the emendation of Boulenger (1898) as unjustified, and changed the epithet of Apostolepis ambiniger from "ambinigra" to "ambiniger." Also, according to the Code, a subsequent spelling of a name, if different from its original spelling, should be considered either an emendation (Art. 33.2), incorrect subsequent spelling (Art. 33.3), or a mandatory change (Art. 34). It should be noted that Boulenger (1898) proposed the combination A. ambiniger after translocating this species from the genus Rhynchonyx to Apostolepis, the latter being a feminine gender genus (considering it is formed by the latinized nominative Ancient Greek nouns "Aposto", "-lépō", and "-is", the latter being a feminine suffix), for an agreement of the subsequently spelled epithet with the gender of its newly allocated genus, and therefore, possibly constituting a mandatory change (Art. 34). However, it should be noted that where the author of a species-group name did not indicate whether the epithet is regarded as a noun or as an adjective, and where it may be regarded as either and the evidence of usage is not decisive, it is to be treated as a noun in apposition to the name of its genus (the original spelling is to be retained, with gender ending unchanged; see Article 34.2.1). Species-group names ending in "-fer" and "-ger" may be either nouns in apposition, or adjectives in the masculine gender; this is the case for the epithet of Rhynchonyx ambiniger. In light of this, we will continue to treat the species as Apostolepis ambiniger.

\section{Species Account}

\section{Apostolepis ambiniger (Peters, 1869)}

Figs. 1-5

Rhynchonyx ambiniger Peters, 1869:438. Holotype male (ZMB 6450; Figs. 1-2) from "angeblich aus Paraguay (= allegedly from Paraguay)." Acquired from "S. Braconnier," likely a private collector from South America [Examined]. Peters and Orejas-Miranda 1970:22; Peters and Orejas-Miranda 1972:588; Harvey 1999:389; Lema et al. 2005:21; Nogueira et al. 2019:29.

Apostolepis ambinigra (Peters, 1869): Boulenger 1896:237; Koslowsky 1898:30; Amaral 1929:40; Hartweg 1932:103; Peters and Orejas-Miranda 1970:22, 1972:588.

Apostolepis dimidiata (Jan, 1862): Peracca 1895:195 [in part, misidentification].

Apostolepis dorbignyi (Schlegel, 1837): Boulenger 1894:347 [in part, misidentification].

Apostolepis vittata (Cope, 1887): Boulenger 1896:56 [in part, misidentification].

Apostolepis tenuis Ruthven, 1927: Amaral 1929:51 [in part, misidentification].

Diagnosis. A species of Apostolepis with the following characters: (1) 15/15/15 dorsal scales; (2) preocular present, contacting nasal; (3) loreal absent; (4) temporals $1+0$ or absent; (5) supralabials six, 2 nd-3rd entering orbit; (6) infralabials $6-7,1$ st-4th in contact with first pair of chinshields; (7) ventrals 219-244 (219-244 in males, 230-242 in females); (8) subcaudals 21-33 (28-33 in males, 21-26 in females), cloacal plate divided; (9) dorsal ground coloration uniformly red or orange with black markings; (10) ventral pattern uniformly yellow or red; (11) first 3-6 vertebrals black, nuchal collars and dorsal stripes absent; (12) distal black caudal blotch overlapping last 9-15 vertebrals and 7-11 subcaudals; (13) terminal scale white or bicolored black dorsally, white ventrally; (14) supralabial blotch large or small, up to four supralabial scales wide; (15) white blotch on rostral vestigial or absent; (16) SVL 390-600 mm, tail length 33-60 mm, tail is $8-10 \%$ of total length and SVL is $90-92 \%$ of total length.

Comparisons. Apostolepis ambiniger occurs near to $A$. dimidiata (characters in parentheses), another red species of Apostolepis that inhabits the Cerrado and Gran Chaco. Apostolepis ambiniger can be distinguished from $A$. dimidiata by its uniformly red dorsal pattern (two lateral 

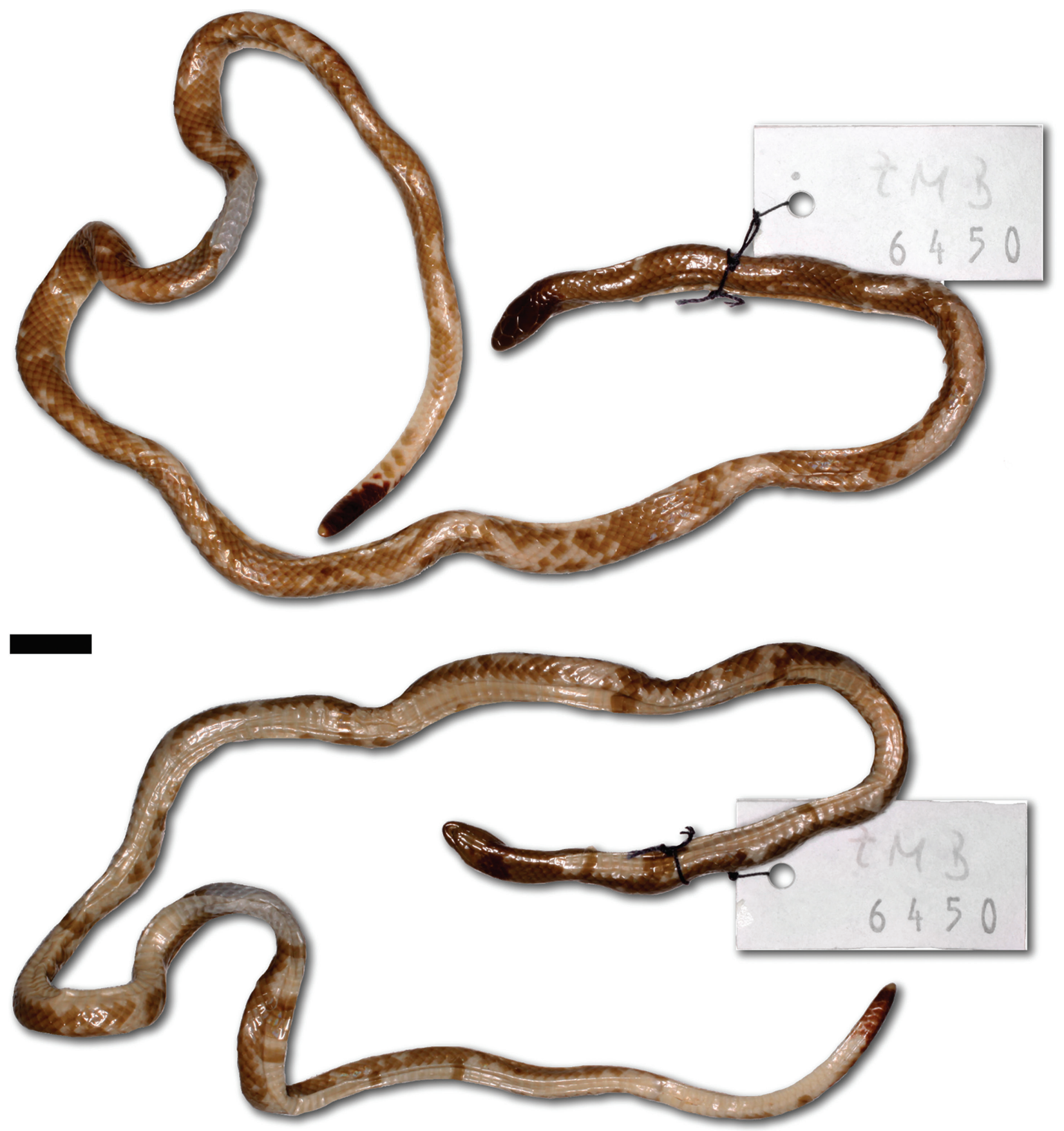

Figure 1. Dorsal and ventral views of Apostolepis ambiniger (Peters, 1868) holotype (ZMB 6450). Scale bar $=10 \mathrm{~mm}$. Photo by Frank Tillack.

black stripes over a red background), 3-6 black dorsal rows in the nuchal area (up to 3 rows), a white or bicolored terminal scale (bicolored or black), rostral white blotch absent or vestigial (present, small, reaching nasal), and slightly bilobed hemipenis, with expanded lips and a distinct sulcus spermaticus (unilobed, inconspicuous sulcus spermaticus).

From Apostolepis goiasensis Prado, 1942, A. ambiniger can be distinguished by its uniformly colored dorsum (three black dorsal stripes), 3-6 black dorsal rows in the nuchal area (0-3 scales), rostral blotch absent or vestigial (large, white, reaching prefrontals), fourth supralabial separated from parietal (in contact), larger size (up to $600 \mathrm{~mm}$ in $A$. ambiniger compared to a maximum known SVL = $392 \mathrm{~mm}$ ), and a calyculate hemipenial apex (spinulate apex).

Several relatively rare congeners may occur in sympatry with $A$. ambiniger in some parts of its range but are unlikely to be confused with it. Unlike $A$. breviceps Harvey, Gonzales and Scrocchi, 2001, A. ambiniger has six supralabials with the second and third entering the orbit (five supralabials, third only entering orbit), two pairs of chinshields (one pair), and infralabials $1-4$ contacting the first chinshield (1-3). Its uniformly red dorsum makes $A$. ambiniger readily distinguished from $A$. lineata (striped), as well as its 1-4 infralabials contacting the first chinshield (1-3). Additionally, unlike $A$. intermedia Koslowsky, 1898, female $A$. ambiniger have 21-26 subcaudals 
(28-31) and unlike both $A$. vittata (Cope, 1887) and $A$. christineae Lema, 2002, male A. ambiniger have 28-33 subcaudals (24-28).

Various extralimital or non-sympatric species, such as Apostolepis adhara França, Barbo, Silva-Jr, Silva and Zaher, 2008, A. albicollaris Lema, 2002, A arenaria Rodrigues, 1993, A. assimilis (Reinhardt, 1861), A. borelli Peracca, 1904, A. cearensis Gomes, 1915, A. cerradoensis Lema, 2003, A. dorbignyi (Schlegel, 1837), A. flavotorquata (Duméril, Bibrón and Duméril, 1854), A. gaboi Rodrigues, 1993, A. kikoi Santos, Entiauspe-Neto, Araújo, Souza, Lema, Strüssmann and Albuquerque, 2018, A. multicincta Harvey, 1999, A. nelsonjorgei Lema and Renner, 2004, A. phillipsi Harvey, 1999, A. quirogai Giraudo and Scrocchi, 1998, A. sanctaeritae Werner, 1924, A. tenuis Ruthven, 1927, and A. thalesdelemai Borges-Nojosa, Lima, Bezerra and James, 2016 have both white or black nuchal collars present, whereas $A$. ambiniger lacks any trace of white nuchal pigment and lacks collars. Furthermore A. longicaudata Gomes in Amaral, 1921, A. niceforoi Amaral, 1935, A. nigrolineata (Peters, 1869), A. pymi Boulenger, 1903, A. serrana Lema and Renner, 2006, and A. striata Lema, 2004, have longitudinal dorsal stripes whereas $A$. ambiniger has a uniformly-colored dorsum.

Osteological comparisons. Among congeners, the skull has only been described for three species: A. assimilis, $A$. cearensis, and A. sanctaeritae. The skull of Apostolepis ambiniger differs from congeners by having edentulous pterygoids (pterygoid teeth 2-4) and only 5-6 dentary teeth (dentary teeth 7-8 in A. assimilis $[n=12]$ and in A. cearensis and $8-10$ in $A$. sanctaeritae $[n=5]$ ) and by exhibiting a rectangular-shaped fronto-parietal suture in dorsal view (U-shaped in A. assimilis and A. sanctaeritae and $\mathrm{W}$-shaped with an antero-median parietal indentation in $A$. cearensis).

It can be further distinguished from $A$. assimilis and A. sanctaeritae by having 4 palatine teeth (5); a strongly enlarged premaxilla with a very broad ascending process, which covers the lateral processes in dorsal view (premaxilla and ascending process less strongly developed and lateral processes visible in dorsal view in $A$. assimilis and premaxilla and ascending process less strongly developed in A. sanctaeritae); nasal and prefrontal dorsally in contact (separated from each other); maxillae with an edentulous and pointed anterior process (anterior part of maxillae blunt and toothed); ectopterygoid partly covered by parietal (not covered by any other bone and therefore completely visible in dorsal view); pterygoids almost entirely covered by roofing skull bones in dorsal view, except for posterior tips (anterolateral region of pterygoids visible and not covered by parietal in dorsal view in $A$. assimilis and lateral edges of pterygoid visible and not covered by parietal in dorsal view in A. sanctaeritae); parietal ridges about parallel to each other, almost reaching to a point where parietal forms a right-angled suture with prootic vs parietal ridges approach each other and almost reach to suture with supraoccipital in A. assimilis and ridges merge in the posterior fifth of parietal and reach to suture with supraoccipital in $A$. sanctaeritae; rectangular frontals in dorsal view (slightly circular [both together] in A. assimilis and irregular shaped and not rectangular in A. sanctaeritae); slender palatines with a straight medial edge (less slender and with medial edge slightly curved in A. assimilis and robust in A. sanctaeritae); parasphenoid rostrum anteriorly surpassing anterior border of frontals and in contact with ventral surface of posteromedial region of nasals (parasphenoid rostrum not surpassing frontals and not contacting nasals); absence of symmetrical bulges medially and backwards pointing projection on each side of the outer lateral edges on the basioccipital (presence of short, blunt, and backwards pointing projection in $A$. assimilis and presence of symmetrical bulges and backwards pointing projection in A. sanctaeritae); slender dentaries and pterygoids (both distinctly broader); similarly high prearticular and surangular crests (prearticular crest is slightly higher than surangular crest).

It further differs from $A$. assimilis by having an unfused parabasisphenoid and basioccipital (fused); anterior end of supratemporal overlapping posterior half of prootic and posterior end not reaching posterior end of exoccipital (anterior end of supratemporal only overlaps posterior part of prootic and posterior end protrudes posteriorly beyond posterior end of exoccipital and is thus the most posteriorly protruding bone of the skull roof); a short retroarticular process of the compound bone (longer); vomerine processes of premaxilla robust and blunt (sharply pointed); exoccipital components of occipital condyle brought together on its dorsal surface (being separated by the basioccipital).

Redescription of holotype. Adult male. Total length $395 \mathrm{~mm}$; SVL $356 \mathrm{~mm}$; tail length $39 \mathrm{~mm}$ (9.8\% of total length, $10.9 \%$ of SVL). Head length $10.32 \mathrm{~mm}(2.61$ $\%$ of total length, $2.89 \%$ of SVL); head width $4.71 \mathrm{~mm}$ (45\% of head length); interorbital distance $2.4 \mathrm{~mm}(51 \%$ of head width); rostro-orbital distance $5 \mathrm{~mm}$; naso-orbital distance $1.5 \mathrm{~mm}$ (14\% of head length). Cervical constriction slightly distinct; head slightly distinct from neck, triangular in dorsal view, narrow anteriorly, arched in lateral view. Pupil sub-elliptical. Rostral conical, 1.81 $\mathrm{mm}$ wide, strongly projected over lower jaw, length of portion visible in dorsal view slightly larger than distance to external anterior edge of frontal. Internasals absent. Prefrontals paired, square, $2.15 \mathrm{~mm}$ long, $1.81 \mathrm{~mm}$ wide; each prefrontal contacting rostral, nasal, preocular, supraocular, and frontal. Frontal hexagonal, $3.12 \mathrm{~mm}$ long, $2.28 \mathrm{~mm}$ wide, contacting prefrontal, supraoculars, and parietals. Supraocular trapezoidal, longer than wider, in contact with posterior edges of prefrontal, lateral edges of frontal, superior edge of preocular, superior edge of postocular, and anterior edges of parietals. Parietals paired; right parietal $3.96 \mathrm{~mm}$ long, $2.25 \mathrm{~mm}$ at its largest width, contacting frontal, supraocular, postocular, fourth through sixth supralabials, anterior temporal, occipital, and interoccipitals. Occipitals square-shaped, enlarged; each occipital contacts a single interoccipital and dorsals. Interoccipitals three, slightly smaller than vertebral and paravertebral rows of dorsals. Nasal triangular, undivided, longer than wide; contacting rostral, prefrontal, first 

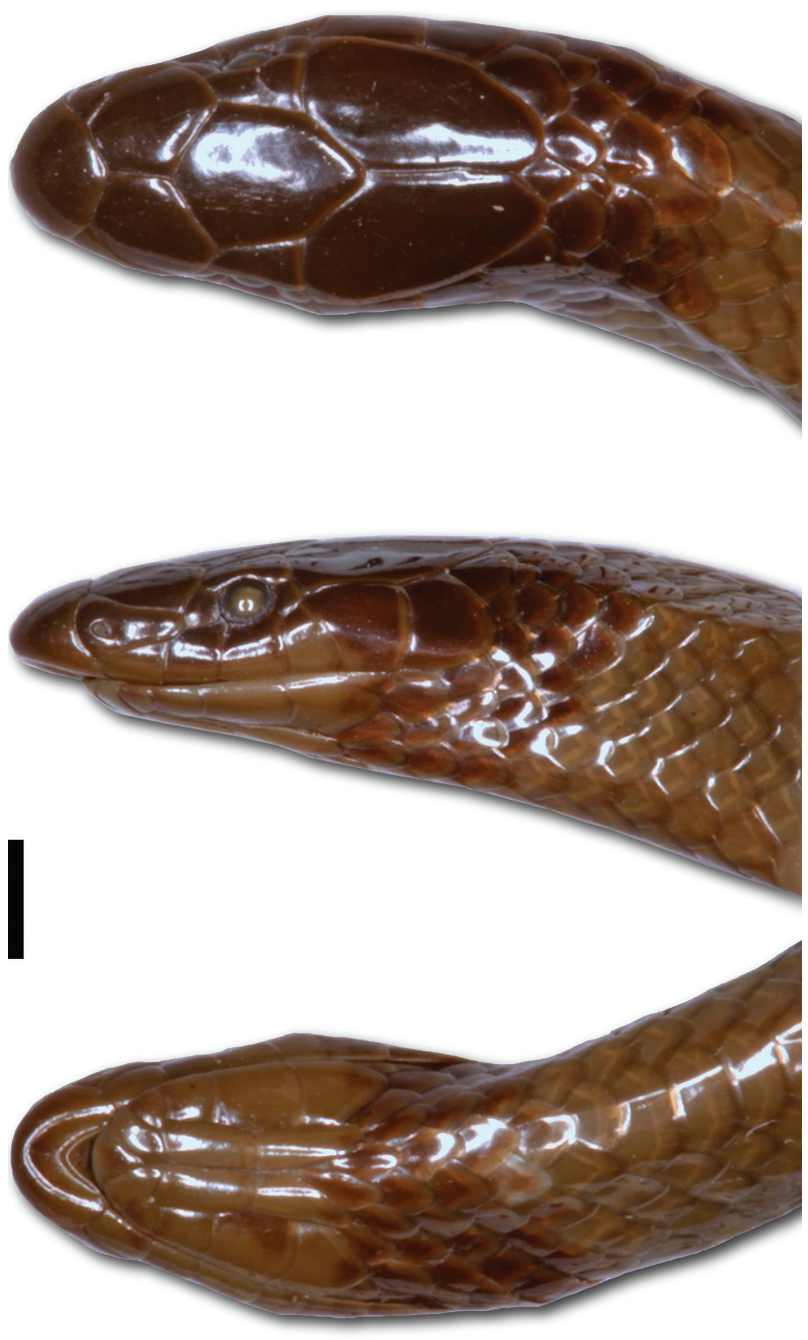

Figure 2. Head view of Apostolepis ambiniger holotype (ZMB 6450). Scale bar $=10 \mathrm{~mm}$. Photo by Frank Tillack.

and second supralabials, and preocular. Nostril in anterior third of nasal, slightly visible from above. Preocular pentagonal; postocular pentagonal, contacting third through fifth supralabials, supraocular and parietal. Temporals 1 +0 , contacting sixth supralabial, latero-posterior edge of parietal, dorsals, and a single interoccipital. Six supralabials, 2-3 entering orbit; first contacting nasal, second contacting nasal and preocular, third and fourth contacting postocular, fifth contacting postocular and parietal, sixth contacting parietal; sixth and fifth supralabials largest and equal in length. Mental triangular, as long as wide. Two pairs of chinshields, second pair longer. Seven infralabials, 1-4 in contact with anterior chinshields, 5-7 in contact with posterior chinshields, first pair in contact with each other behind mental; fourth and fifth infralabials largest, equal in size. Dorsals smooth, in 15/15/15 rows. Pre-cloacal scale divided. Ventrals 219; preventrals 5. Subcaudals paired, 34/34. Terminal scale acuminate, curved ventrally.

Head uniformly dark brown dorsally and laterally, dark brown pigmentation covering up to five dorsal rows. Rostral uniformly dark brown on dorsal surface, with diffuse white pigmentation on its ventral surface and anterior edges. Supralabial blotch single and large, covering in-
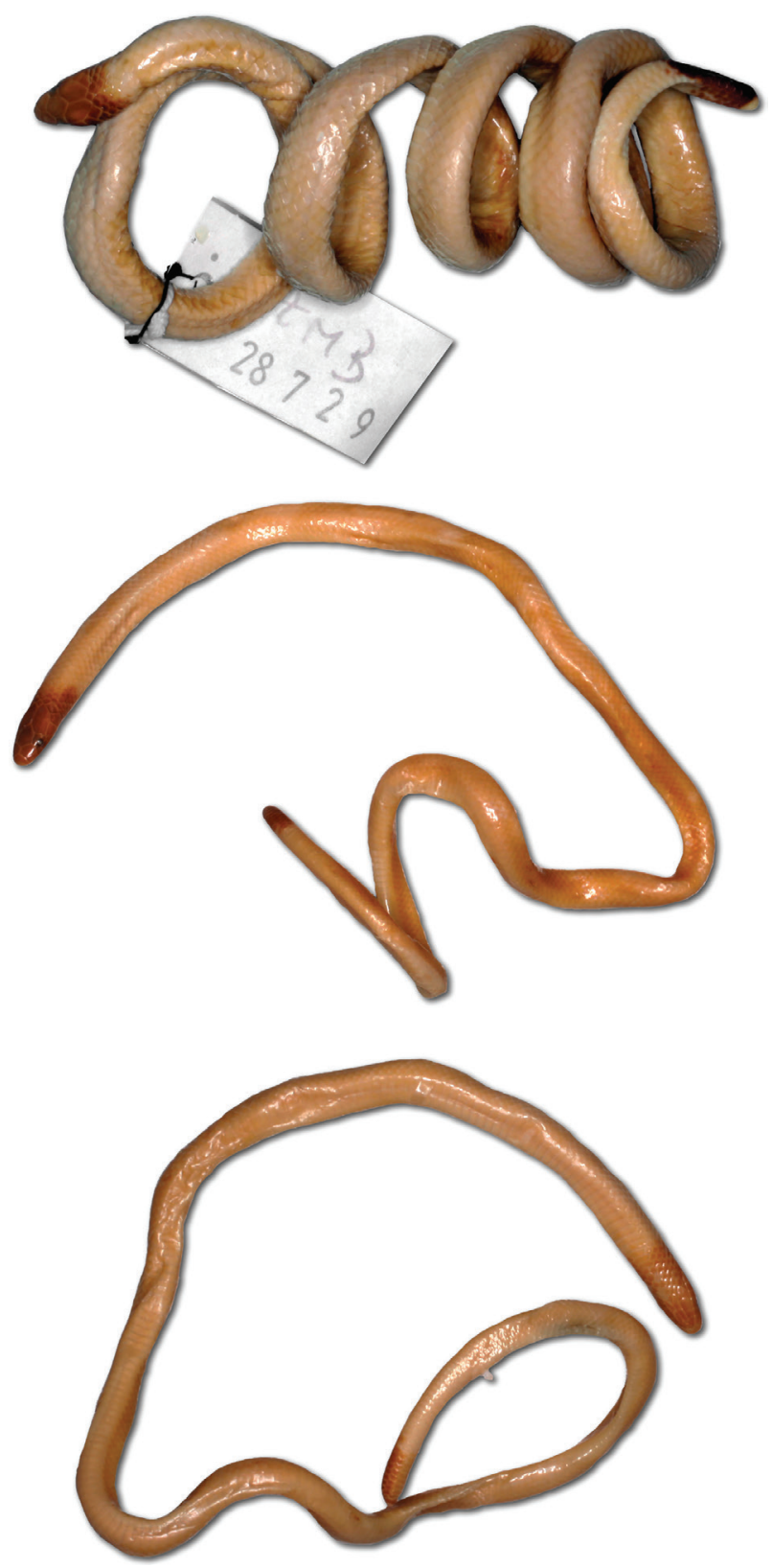

Figure 3. Dorsal view of Apostolepis ambiniger specimens (Top: ZMB 28279; Middle and Down: ZMB 32144). Scale bar = $10 \mathrm{~mm}$. Photo by Frank Tillack.

ferior edges of supralabials 1-5. White and black nuchal collars absent. Diffuse dark brown pigmentation on outer edges of infralabials and chinshields. Dark brown gular collar complete, covering up to four rows of gular scales. Dorsal background coloration light tan (discolored and dehydrated across ventrals 153-164). Dorsal stripes absent. Ventral and subcaudal coloration uniformly light tan. Caudal blotch dark brown, extending proximally 15 vertebrals and seven subcaudals. Terminal scale bicolored, dark brown dorsally, white ventrally.

Coloration in life. Dorsal head uniformly black, without rostral blotches or nuchal collars; lateral head uniformly black, or with small to vestigial white supralabial blotch covering no more than two scales. Infralabials uniformly black, or with white blotch covering 2-3 scales. Ventral 

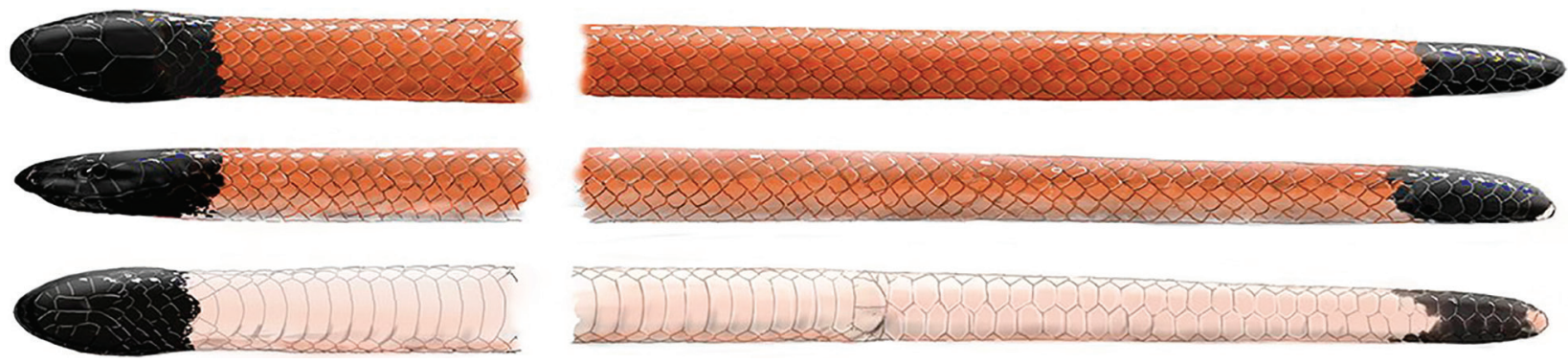

Figure 4. Color pattern of Apostolepis ambiniger in life. Illustration by Arthur Tiutenko.

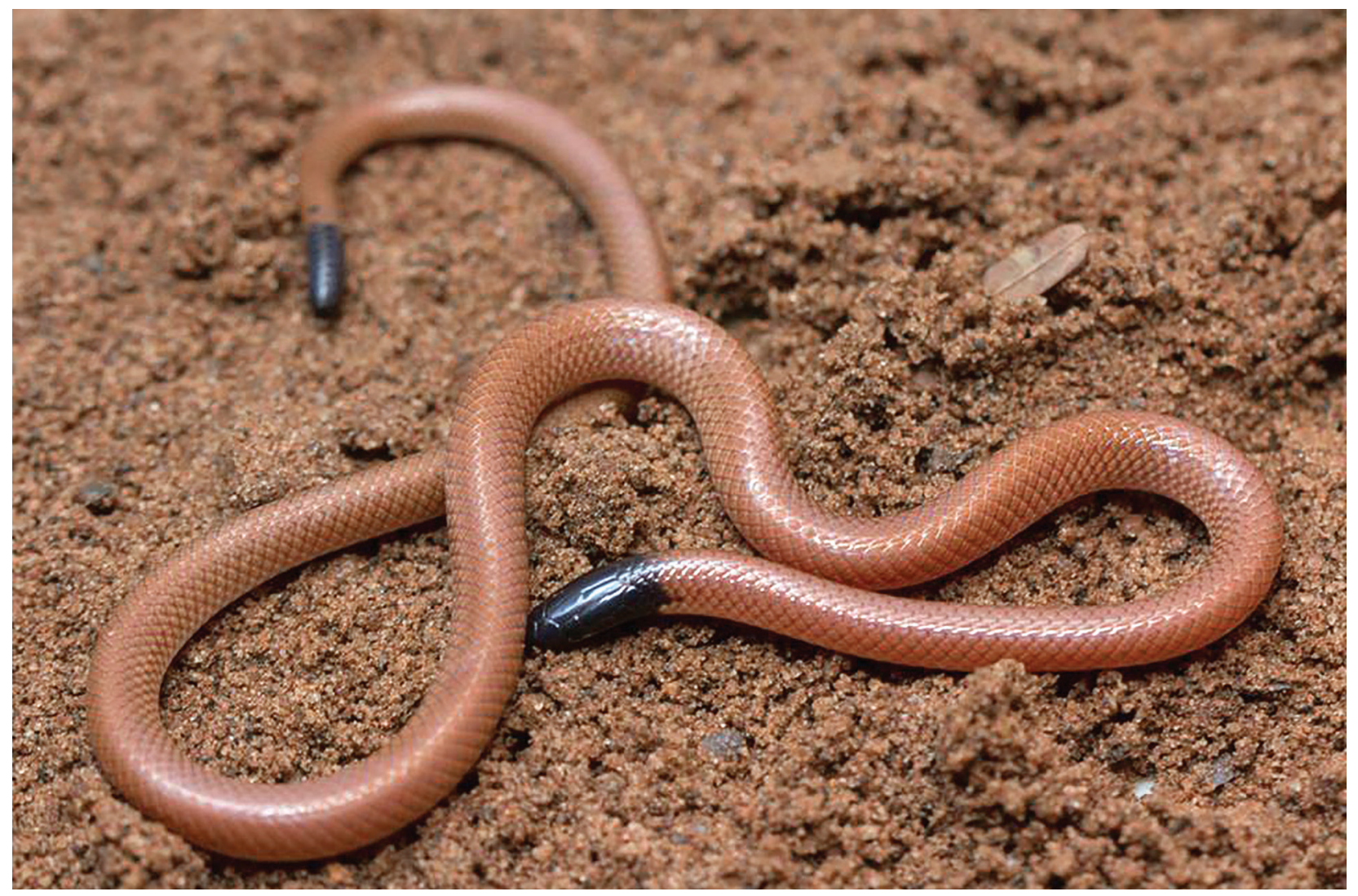

Figure 5. Specimen of Apostolepis ambiniger in life (unvouchered), from San Lorenzo, Departamento Central, Paraguay. Photo by Nicolas Martinez.

portion of head black, with diffuse white pigmentation on posterior chinshields. Rostral lacking white blotch. Dorsal background coloration red or orange (Figs. 4-5); first 3-6 dorsal scale rows black. Ventral coloration yellow or light red. Distal black caudal blotch overlapping last 9-15 vertebrals and 7-11 subcaudals. Terminal scale white or bicolored black dorsally, white ventrally.

Coloration in preservative. In preservative, black coloration turns dark brown, red coloration gradually becomes light tan, and yellow ventral coloration becomes uniformly $\tan$ (Figs. 1-3).

Hemipenis. Hemipenis slightly bilobed, noncapitate, semicalyculate (Fig. 6). Lobes slightly differentiated, present on distal portion of capitulum; lobes rounded, spinules centrifugally oriented from organ's medial surface; lobes and capitulum sparsely covered by papillate calyces on sulcate and lateral sides; capitulum conspicuous in both sulcate and asulcate sides, slightly smaller than hemipenial body, and positioned slightly above bifurcation of sulcus spermaticus. Bifurcation of sulcus spermaticus in middle of organ. Capitular groove distinct on both sides of organ. Sulcus spermaticus branching centrolineally, with wide invagination on apex and capitulum; margins of sulcus spermaticus wide, bordered by expanded lips. Hemipenial body moderately long for Apostolepis, subcylindrical; on sulcate surface, hemipenial body covered by moderate to large hooked spines; on asulcate side, hemipenial body with large basal naked pocket, extended to medial and apical regions, with enlarged spines; $2-5$ rows of enlarged spines present on lateral portion of sulcate side and medial and apical region of asulcate side.

Sexual dimorphism. Males of Apostolepis ambiniger have relatively longer tails $\left(F_{7,6}=17.02, P=0.002\right)$, few- 

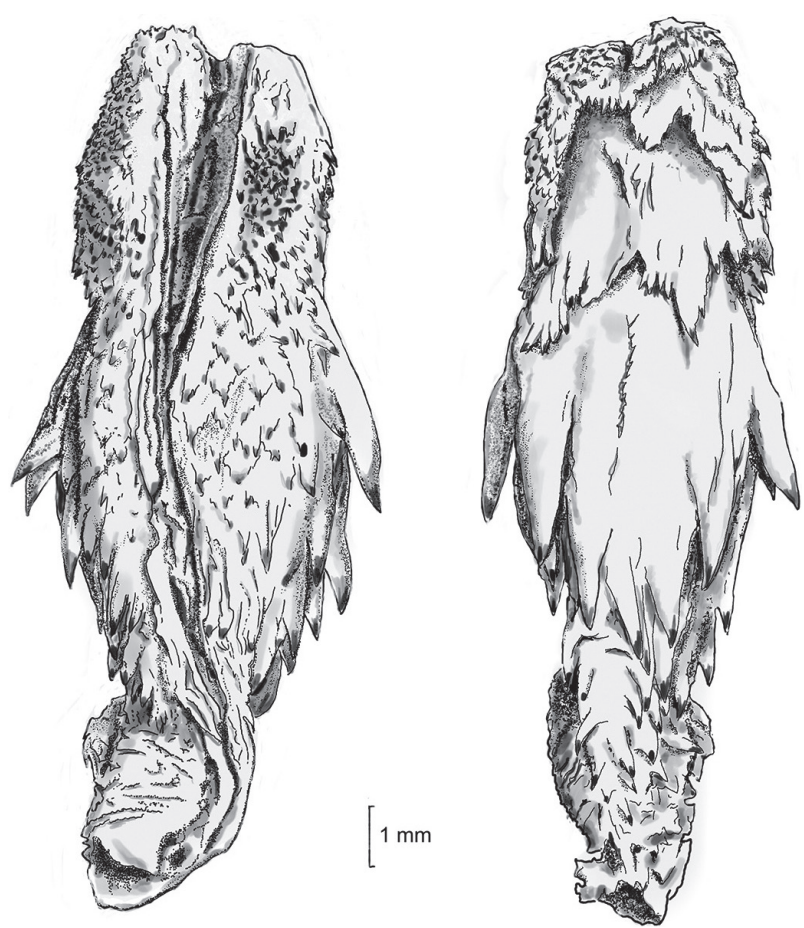

Figure 6. Hemipenis of Apostolepis ambiniger (MHNP 3493) on sulcate (left) and asulcate (right) sides. Illustration by Arthur Tiutenko.

er ventrals $\left(t_{10,8}=2.77, P=0.014\right)$, and more subcaudals $\left(t_{11,8}=4.19, P=0.001\right)$ than females (Fig. 7). In males, the tail is $8-10 \%(9 \pm 0, n=7)$ of total length and SVL is $90-92 \%(91 \pm 0, n=7)$ of total length, whereas, in females, the tail is $6-9 \%(7 \pm 0, n=6)$ of total length and SVL is $91-94 \%(93 \pm 0, n=6)$ of total length. Males have 218-244 (229 $\pm 8, n=10)$ ventrals and 27-34 (30 $\pm 2, n$ $=11)$ subcaudals, whereas females have 230-251 (239 \pm $6, n=8)$ ventrals and 23-31 (25 $\pm 3, n=8)$ subcaudals.

Snout osteology. The snout complex is composed of the premaxillae, nasals, septomaxillae, vomers, and prefrontals (Figs. 8-10). The single premaxilla is edentulous, thick and robust, 1.8 times broader than high, with a stout, posterodorsally oriented ascending process, distinctly broader than high and with the lower region of the process defining the widest part of the premaxilla in anterior view, dorsal surface slightly concave, posterodorsally broadly triangular at the articulation with the anterior end of the nasals; the transverse processes are posterolaterally oriented, not visible in dorsal view, long, approaching but still distinctly separated from the maxillae; between the lateral wings of the ascending process and the transversal processes, which protrude laterally about equally far in anterior view, there is a deep narrow notch; the vomerine processes are posteriorly oriented with parallel medial edges, robust, about triangular, blunt, dorsally contacting the anteroventral part of the body of the septomaxilla, largely separated from the anterior end of the vomers; the ventral surface of the premaxilla pierced by about 4 foramina.

The paired nasals are about rectangular in dorsal view, about twice as long as broad, convex, in medial contact
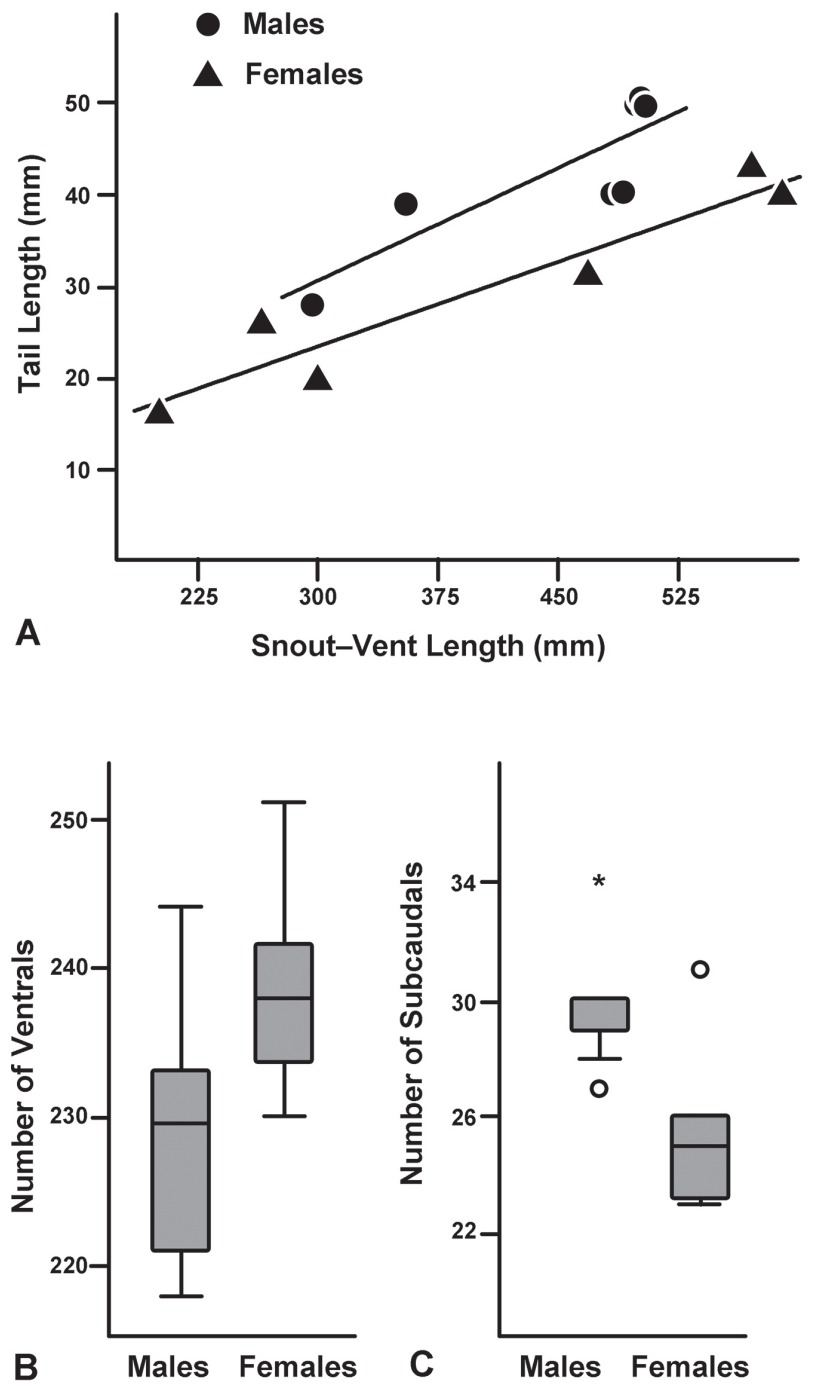

Figure 7. Sexual dimorphism in mensural (A) and meristic (B, C) characters of Apostolepis ambiniger. We used interpolation to calculate percentiles of the box plots. Open circles in C represent near outliers and an asterisk represents a far outlier.

along a straight suture, the front edges form a broad $\mathrm{V}$-shaped anterior region, that frames the ascending process of the premaxilla; the lateral edges are curved downwards; posteriorly the nasals share a loose transverse suture with the frontals; posterolaterally is a small contact region with the prefrontals; the posteroventral process of the nasal contacts the anteroventral process of the frontal posteriorly and the anterior tip of the dorsally oriented process of the parasphenoid rostrum ventrally; the vertical lamina of the nasals laterally contacting the medial edge of the septomaxillae.

The paired septomaxillae are about 2.6 times longer than broad, separated from each other by the vertical laminae of the nasals; each with a broad ascending conchal process, freely extending laterally, marginally visible beyond the lateral edge of the nasal in dorsal view, but not reaching the height of the lateral nasal edge; the anteromedial process of the septomaxilla is about one fifth the length of the septomaxilla, curved and anterolaterally oriented, each reaching over about half the depth of the premaxilla and contacting the posterior lamina of the lateral 


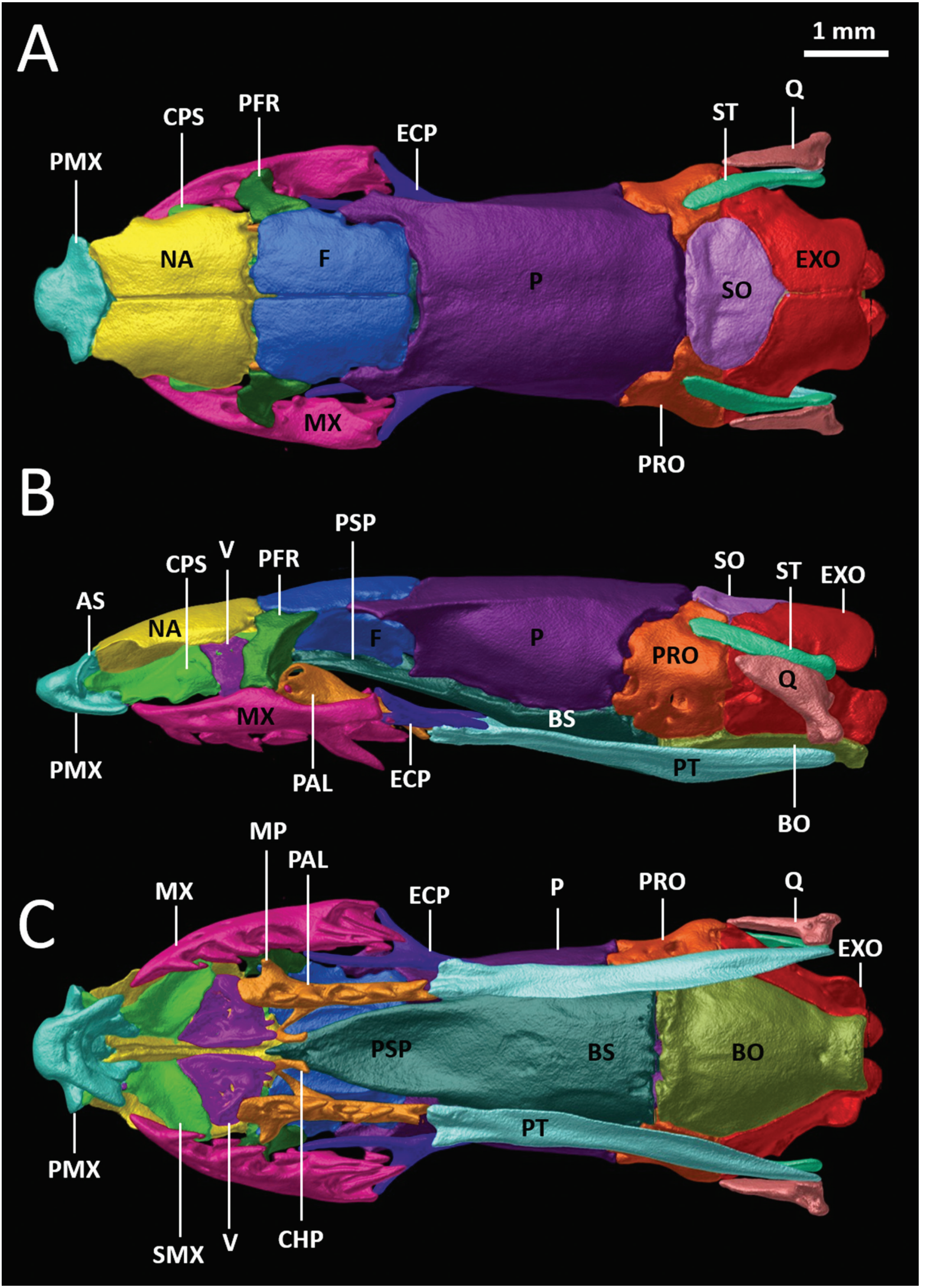

Figure 8. Micro-CT images of the skull without mandibles of the holotype of Apostolepis ambiniger (ZMB 6450) in A) dorsal, B) lateral, and C) ventral views; AS (ascending process of premaxilla); BO (basioccipital); BS (basisphenoid); CHP (choanal process of palatine); CPS (conchal process of septomaxilla); ECP (ectopterygoid); EXO (exoccipital); F (frontal); MP (maxillary process of palatine); MX (maxilla); NA (nasal); P (parietal); PAL (palatine); PFR (prefrontal); PMX (premaxilla); PRO (prootic); PSP (parasphenoid rostrum); PT (pterygoid); Q (quadrate); SMX (septomaxilla); SO (supraoccipital); ST (supratemporal); V (vomer). 
wing of the premaxillary ascending process, the anterior tip of the process is hardly visible in dorsal view; the posteromedial process is long and thin, makes up about $40 \%$ the length of the entire septomaxilla, medially contacting the vertical lamina of the nasal, the rounded posterior tip contacting the anteroventral tip of the frontal, directly lateral to the ventral nasal-frontal contact region; the septomaxillary body is a complex structure made of thin bone material with a rounded indentation in its posterior view; the anterior region of the septomaxillary body is medially contacting the dorsal surface of the premaxillary vomerine process; the posterior region of the septomaxillary body and the ventral surface of the anterior two thirds of the posteromedial process of the septomaxilla contact the anterior and anterodorsal region of the vomer.

The paired vomers are complex structures, about 1.3 times longer than broad, approaching, but not contacting each other medially, and with the anterior and posterior region diverging; anteriorly and anterodorsally contacting the septomaxilla, laterally approaching but not contacting the anterior region of the palatine; the body of the vomer is made of thin bone material and globular with an anteriorly oriented opening; the bifurcate vertical posteromedial laminae are diverging dorsally and ventrally, framing but not contacting the choanal process of the palatine anteriorly.

The paired prefrontals are 1.5 times longer than broad, greatly separated from another, oriented slightly oblique, forming the anterior margin of the orbits; the anterolateral margin is undulated; the posterolateral margin is slightly concave; the dorsal edge contacts the anterolateral edge of the frontal along a slightly curved suture; anterodorsally there is a small contact region with the posterolateral edge of the nasal; the ventral edge contacts the dorsal surface of the maxilla and approaches the maxillary process of the palatine, without contacting it; in rear view, a triangular medially directed process is visible at about midheight of the prefrontal and a large slightly oval lacrimal foramen is visible in the ventromedial region.

Braincase osteology. The paired frontals are rectangular, about 1.8 times longer than broad, almost similar in size as the nasals, slightly convex, in contact medially with a straight suture, with undulated lateral margins (Fig. 8); about one fifth of the lateral margin of each frontal, directly posterior to the region of greatest width of the frontal participates in the formation of the dorsal margin of the orbit; the anterior edge is almost straight, forming a loose transverse suture with the posterior edge of the nasal; the anterolateral edge of the frontal forming an oblique, marginally curved suture with the prefrontals; the posterior edge is straight, contacting the parietal along half of its length; the posterior half of the lateral edge of each frontal contacting the medial edge of the anterolateral process of the parietal, leading to an exclusion of the frontal from the orbit in that region; anteroventrally the frontal contacts the nasal and directly lateral to this contact zone it has a bulge whose anterior surface contacts the posterior end of the posteromedial process of the septomaxilla; laterally each frontal has a ventromedially oriented, concave lamina, the laminae of both frontals contact each other medially along the anterior third of their length; anteromedially, the frontal exhibits a vertical lamina along the first fifth of the bone, which is ventrally fused to the lateral lamina, forming a short tubular structure in the anterior region of each frontal, the vertical lamina of both frontals are in firm medial contact; posterior to the tubular structure, the lateral lamina of both frontals are distinctly separated from each other, with their medial edges being about parallel to each other; on the ventral surface of the contact zone of the vertical lamina of the frontals is a facet, in which the anterior part of the dorsal process of the parabasisphenoid intrudes, posterior to it the dorsal process protrudes into the gap between the two lateral lamina, and contacts them with its lateral edges.

The single parietal is elongate, about 1.5 times longer than broad, has a slightly convex dorsal surface and is almost entirely rectangular, except for the anterolateral processes; the anterolateral processes are moderately long and robust, framing the lateral borders of the frontals and forming the posterior and posterodorsal margin of the orbit; the anterior border is almost straight, but with a medial elongated notch, so that the parietal is not in contact with the frontal bones in this area; the anterolateral processes extend straight anteriorly, run approximately parallel to each other and form a right angle to the anteromedial edge of the parietal, resulting in a rectangular-shaped fronto-parietal suture in dorsal view; in dorsal view, the parietal covers the pterygoids completely; a ridge extends dorsally on both sides from the anterolateral process in posterior direction, almost reaching to a point where the parietal forms a right-angled suture with the prootic, both ridges are about parallel to each other; lateral to the dorsal ridges, the parietal slopes downwards with a slightly convex surface to meet ventrally the posterior half of the parasphenoid rostrum and about the anterior half of the basisphenoid portion of the parabasisphenoid; posterolaterally the parietal contacts the anterior margin of each prootic and forms the anterior limit of the foramen for the maxillary branch of the trigeminal nerve at the lateral suture with the prootic; the posterodorsal region of the parietal forms an almost straight suture with the supraoccipital. Postorbitals are absent.

The single supraoccipital is ovaloid, 1.5 times broader than long, slightly concave, and the anterior region is slightly elevated; anteriorly it contacts the parietal, anterolaterally the prootics, and posteriorly the exoccipitals; it is distinctly separated from the supratemporals; laterally the supraoccipital extends downwards (internal) to contribute to the dorsomedial walls of the otic capsules.

The paired exoccipitals are irregularly shaped, and in medial contact along a straight suture; each has a little pronounced, oblique, dorsolateral ridge, which is parallel to the inner margin of the supratemporals; anterodorsally each exoccipital contacts the supraoccipital with a slightly curved suture, anterolaterally the prootic, ventrally the basioccipital and dorsolaterally the supratemporals; the fenestra ovalis is situated at the suture between the prootic and the exoccipital, and the exoccipital forms the posterior margin of the fenestra; posterior to the fenes- 


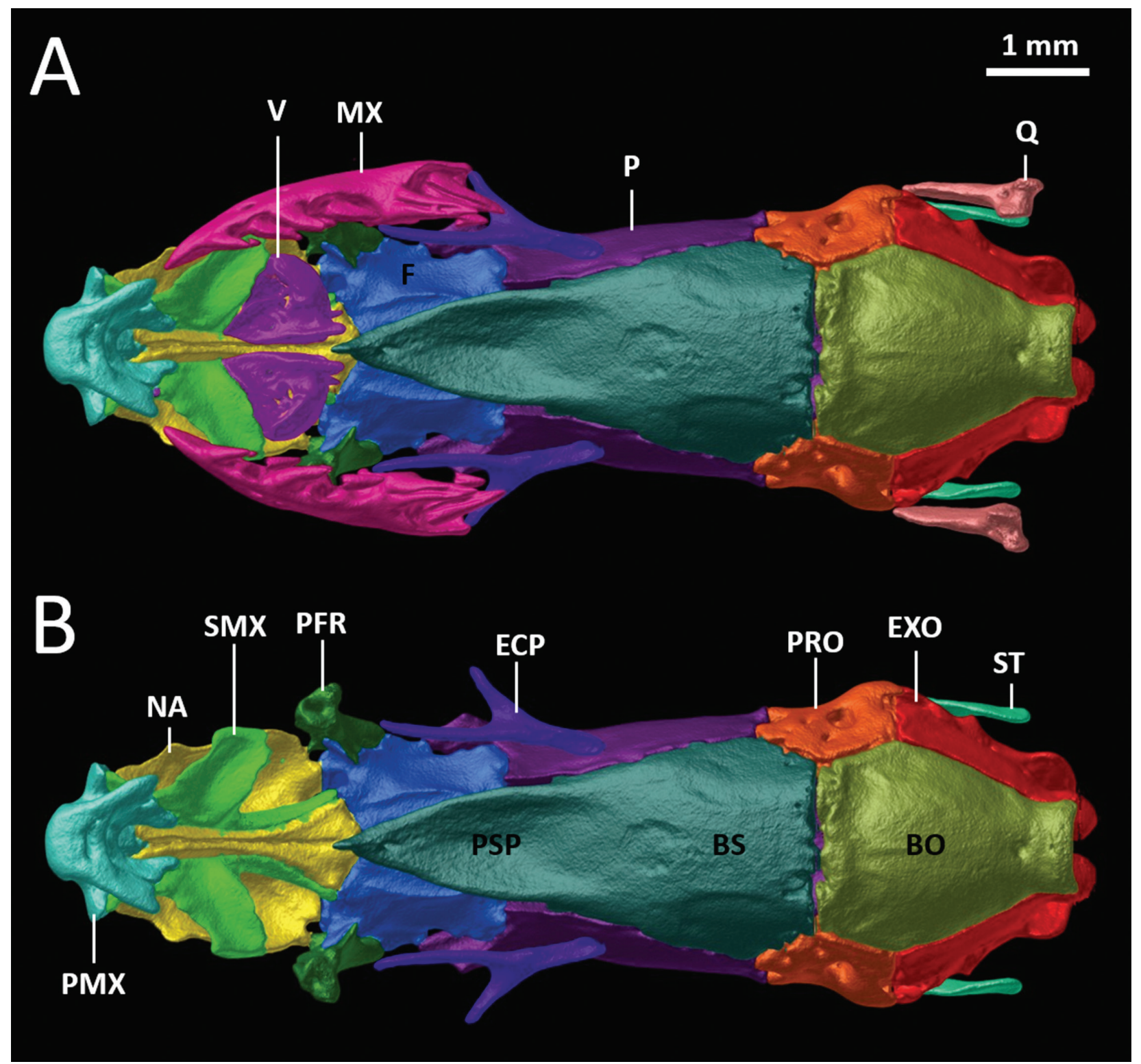

Figure 9. Micro-CT images of the skull without mandibles of the holotype of Apostolepis ambiniger (ZMB 6450) in ventral view: (A) palatines, and pterygoids removed, (B) maxillae, palatines, pterygoids, quadrates and vomers removed; BO (basioccipital); BS (basisphenoid); ECP (ectopterygoid); EXO (exoccipital); F (frontal); MX (maxilla); NA (nasal); P (parietal); PFR (prefrontal); PMX (premaxilla); PRO (prootic); PSP (parasphenoid rostrum); Q (quadrate); SMX (septomaxilla); ST (supratemporal); V (vomer).

tra ovalis halfway to the foramen magnum is a recess, bearing tow (left exoccipital) or three (right exoccipital) foramina; posteroventrally, the exoccipital components of the occipital condyle are in close contact, excluding the posterior process of the basioccipital from participation in the foramen magnum; the exoccipital contributes to the formation of the posteroventral, posteromedial and posterolateral wall of the otic capsule; the exoccipital is the most posteriorly protruding bone of the skull roof.

The single basioccipital is almost hexagonal shaped, 1.2 times longer than broad, convex; it contacts the parabasisphenoid complex anteriorly, the prootics anterolaterally, and the exoccipitals posterolaterally; posterodorsally the basioccipital is overlain by the exoccipital components of the occipital condyle, preventing its participation in the formation of the foramen magnum; the posterior end of the basioccipital (part of the occipital condyle), is rectan- gular-shaped in ventral view and quadrant-shaped in posterior view; the widest part of the basioccipital is at the sutures with the prootics and exoccipitals; the surface of the basioccipital is relatively smooth and the lateral edges are straight, without backwards pointing projections; a small foramen is present medially in the posterior region, at about where the basioccipital part of the occipital condyle begins.

The paired prootics are ovaloid in lateral view, 1.25 times higher than long; each prootic contacts the parietal anteriorly, the supraoccipital dorsally, the exoccipital posteriorly, the parabasisphenoid complex anteroventrally, the basioccipital posteroventrally, and the anterior part of the supratemporal on its dorsal surface; at the suture with the parietal the prootic forms the posterior border of the foramen for the maxillary branch of the trigeminal nerve and at the suture with the exoccipital it forms the anterior 
margin of the fenestra ovalis; the foramen for the mandibular branch of the trigeminal nerve is posterolaterally oriented and situated slightly posterior and slightly below the central part of the prootic in lateral view; there are three further foramina on the lateral surface of the prootic: a medium-sized foramen is situated in between both trigeminal nerve foramina, a larger foramen in the anteroventral region of the prootic, at the suture with the parabasisphenoid, and a small foramen is placed in between the posterior trigeminal nerve foramen and the contact region of the prootic with the suture of the parabasisphenoid and the basioccipital; in dorsal view, the prootic bears a depression in the posterior region in which the anterior tip of the supratemporal rests; the prootic contributes to the formation of the anteroventral, anteromedial and anterolateral wall of the otic capsule; few small foramina pierce the medial laminae of each exoccipital.

The unpaired parasphenoid and basisphenoid are fused to form the parabasisphenoid, forming an elongate structure, about 2.2 times longer than broad, that occupies most of the skull floor, and is concave in the parasphenoid region and convex in the basisphenoid region; the basisphenoid portion is each roughly rounded, and the parasphenoid rostrum is lanceolate with a pointed anterior tip; the anterior half of the parasphenoid rostrum bears a dorsally oriented process, which protrudes into the gap between the two vertical lamina of the frontals, and contacts them with its lateral edges; the anterior tip of the parasphenoid rostrum surpasses the anterior border of the frontals in ventral view; the anteriormost tip of the parasphenoid rostrum is freely extending, but slightly posterior to the tip, the anteriormost part of the dorsal process of the parasphenoid rostrum contacts the ventral surface of the posteromedial region of the nasals; the parasphenoid rostrum is distinctly separated from the choanal process of the palatine, the posterior ending of the vomers, and the septomaxillae; dorsolaterally the parabasisphenoid contacts the parietal, and the prootics posterior to it, and reaches its greatest width at the sutures between the parietal and the prootics; a foramen is located on each side in the posterolateral part of the basisphenoid portion, at the suture with the prootics; in dorsal view the parabasisphenoid is pierced by some foramina in the lateral region of the bone.

Palatomaxillary arch osteology. The palatomaxillary arch is composed of the maxillae, ectopterygoids, palatines, and pterygoids (Fig. 8-10). The maxillae are elongate, account for about one-third of the length of the skull, and are about 5.6 times longer than high, extending from shortly behind the level of the lateral processes of the premaxilla to behind the central region of the orbit, forming most of the lower margin of the orbit laterally; the maxilla is slightly triangular in lateral view, ignoring the teeth, with the highest point at about half of its length; the maxillae are slightly arched towards the premaxilla and have an edentulous anterior pointed process; the ventral surface of the maxilla bears four tooth loci, with curved, and rear facing anterior teeth, followed posteriorly, after a small interspace, by a pair of large deeply grooved fangs, situated below the eye; the posterior end of the maxilla is approximately rectangular and without a tooth-like spur; of the cranial bones the maxilla only contacts the prefrontal on its dorsal surface at its highest point; the palatine process is short, approaches but not contacts the maxillary process of the palatine; a small, knob-like ectopterygoid process is visible, but remains slightly separated from the anterior tip of the medial process of the ectopterygoid.

The paired ectopterygoids are divining rod-shaped, deeply bifurcated anteriorly, with a longer medial process than lateral process; in dorsal view of the skull, the lateral process and the anterior half of the medial process are visible, whereas the rest of the ectopterygoid is covered by the parietal; the two anterior processes are directed anterolaterally and frame the posterior end of the maxilla laterally and medially without touching it, forming an almost closed maxilo-ectopterygoid fenestra; the ventral surface of the flattened posterior process has a facet, where it firmly contacts the dorsal surface of the anterolateral portion of the pterygoid.

The paired pterygoids are edentulous, flattened, elongate and slender, about 9.7 times longer than broad, corresponding to approximately half the length of the skull; except for the firm contact with the ectopterygoid, the pterygoid does not contact any of the other skull bones; in dorsal view of the skull, only small portions of the posterior tips are visible and not completely covered by the supratemporals, whereas the rest of the pterygoids are completely covered by the roofing skull bones; the anteromedial tip of the pterygoid dorsally overlaps only marginally the posteromedial tip of the palatine without touching it; in ventral view, the lateral border of the pterygoid is slightly curved posterolaterally; the medial borders of both pterygoids are nearly parallel to each other in the anterior third, with the smallest distance between them at their anterior tips; the medial border of the last two-thirds of the bone gradually tapers posterolaterally, resulting in the greatest distance between both pterygoids at their posterior tips; the posterior end of the pterygoid approaches medially the ventromedial process of the quadrate without touching it.

The paired palatines are elongate and slender, about 7.3 times longer than wide, when not considering the choanal and maxillary processes, and correspond to $24 \%$ of the length of the skull; their medial edge is straight, and both palatines are about parallel to each other; the ventral surface has four tooth loci; the teeth are subequal, curved, and rear facing; of the cranial bones the palatine only contacts the medioventral region of the prefrontal on the dorsal surface of its maxillary process; the anterior portion of the palatine, anterior to the tooth line is almost quadrangular and approaches the ventrolateral part of the vomer dorsally, without contacting it; dorsomedially, a long, thin choanal process rises and curves downwards in a semicircle, approaching but remaining distinctly separated from its counterpart medially; the short, about triangular maxillary process is situated on the lateral surface of the palatine at the level of the first tooth, directed anterolaterally, approaching but not contacting the palatine process of the maxilla; the posterior part of the palatine 
behind the tooth line is bifurcated, with a slightly shorter ventrolateral process and a slightly longer dorsomedial process, both tapering towards the posterior end, and the anterior part of the pterygoid extends into the gap between the two processes without touching them.

Suspensorium and mandible osteology. The suspensorium is composed of the supratemporals and the quadrates. Each mandible is composed of the dentary, splenial, angular, and compound bone (Figs. 10-11). The supratemporals are laminar, elongate, more than six times longer than wide, slightly curved, and slightly oblique; in dorsal view, slightly more than the anterior half of each supratemporal overlaps and firmly contacts the posterior half of the prootic and the anterolateral part of the exoccipital over well-defined facets; distinctly separated from the parietal; the posterolateral region approaches the dorsomedial aspect of the quadrate, without touching it; the posterior end does not protrude posteriorly beyond the quadrate and ends distinctly before the posterior end of the exoccipital.

The quadrates are flattened and broad dorsally, tapering dorsoventrally in lateral view, but gradually increasing in width in rear view; they are oriented oblique, from anterodorsally to posteroventrally; the posterodorsal part approaches the posterolateral region of the supratemporal medially; the medial part has a short process, which corresponds to the contact region with the columella auris, but the columella auris is not visible; the ventral part is bifurcated, with the medial branch being broader than the lateral branch and both together spanning the glenoid cavity of the retroarticular process of the mandible; the quadrate does not exceed the posterior limit of the skull roof.

The dentaries are elongate and slender, making up about $40 \%$ the length of the mandible, and are slightly curved anteromedially; the dorsal surface bears five (left dentary) or six (right dentary) tooth loci; the teeth are subequal, curved and rear facing; the lateral face is slightly convex with a mental foramen located at about the level of the fifth tooth, almost in the medial region of the dentary; at about the level of the last tooth, the dentary branches into a shorter dorsal process, which overlays the anterior part of the compound bone, and a longer lanceolate ventral process; the gap between the dorsal and ventral processes is mainly filled by the splenial, whereas the posteriormost part of the ventral process contacts the anteroventral part of the angular; the ventral process runs with its dorsal surface parallel and close along the anterior part of the medioventral region of the compound bone without touching it; in medial view, the dorsal process is bifurcated in its posterior region, distinctly behind the last tooth, with a longer dorsolateral branch and a very short ventromedial branch.

The splenials are elongate, triangular, tapered anteriorly, about 4.2 times longer than high, and represent the smallest of the mandibular bones, making up about onefifth of the mandibular length; the anterior mylohyoid foramen is centrally positioned in the posterior part of the bone at the level of its greatest height; the posterior edge of the splenial firmly contacts the anterior region of the angular; the dorsal edge is notched in the posterior region, just before the summit of the triangle.

The angulars are elongate, triangular, tapered posteriorly, almost five times longer than high, and represent the second smallest of the mandibular bones, making up about one-fourth of the mandibular length; each angular contacts the splenial anteriorly, the compound bone laterally and dorsally, the posteriormost tip of the medial process of the dentary, and the posteromedial surface of the ventral process of the dentary; the posterior mylohyoid foramen is on the lateral surface in the anterior third of the bone.

The compound bones are elongate and slender, about 8.6 times longer than high, and represent the largest of the mandibular bones, making up about two-thirds of the length of the mandible; the prearticular and surangular crests are about similar in height, and therefore neither of them is visible in lateral or medial view; in lateral view, the compound bone tapers anteriorly, loosely fitting between the dorsal and ventral processes of the dentary; an anterodorsally oriented foramen is present in the anterior region on the lateral surface of the compound bone; the retroarticular process is moderately long, slightly medially directed, and does not surpass beyond the posterior end of the exoccipital.

Geographic distribution. This species has been historically recorded in Argentina, Brazil, Bolivia, and Paraguay (Nogueira et al. 2019). The record from Argentina is based on a specimen (USNM 73458) from Estancia Breyer, Patquia, La Rioja; although this specimen clearly is A. ambiniger, its locality is determined here as incorrect, as other specimens from the same collector have been corrected as being from Paraguay (see Dixon and Hendricks 1979). Nogueira et al. (2019) present 11 records of the species for Brazil. However, except for one, none of these records are based on direct examination of specimens, and only a collection acronym is given in the appendix of specimens examined (ZUFMS), referring to the Coleção Zoológica Universidade Federal do Mato Grosso do Sul. To our knowledge, there are no specimens of $A$. ambiniger deposited in this collection, and this is further corroborated by the curator (Diego J. Santana, personal communication). The single vouchered record of $A$. ambiniger from Brazil reported by Nogueira et al. (2019) is a specimen (FMNH 69934) from "Fazenda Ipanema," Varnhagem (currently Iperó municipality), São Paulo, Brazil. This specimen is reanalyzed here, and redetermined as $A$. dimidiata. In light of these findings, the records of Nogueira et al. (2019) should be considered as dubious, as to this moment, there are no verifiable records of $A$. ambiniger from Brazil. Nogueira et al. (2019) also report a specimen (USNM 108809) from "Bolivia," with coordinates from Buena Vista, Bolivia. However, based on the collection data, this specimen is redetermined here as being from Trinidad, Departamento Central, Paraguay. The single vouchered record from Bolivia is reported by Lema et al. (2005), a specimen (LACM 37647) from Chuquisaca, El Salvador, Bolivia; this record is herein examined by us and redetermined as Apostolepis mul- 

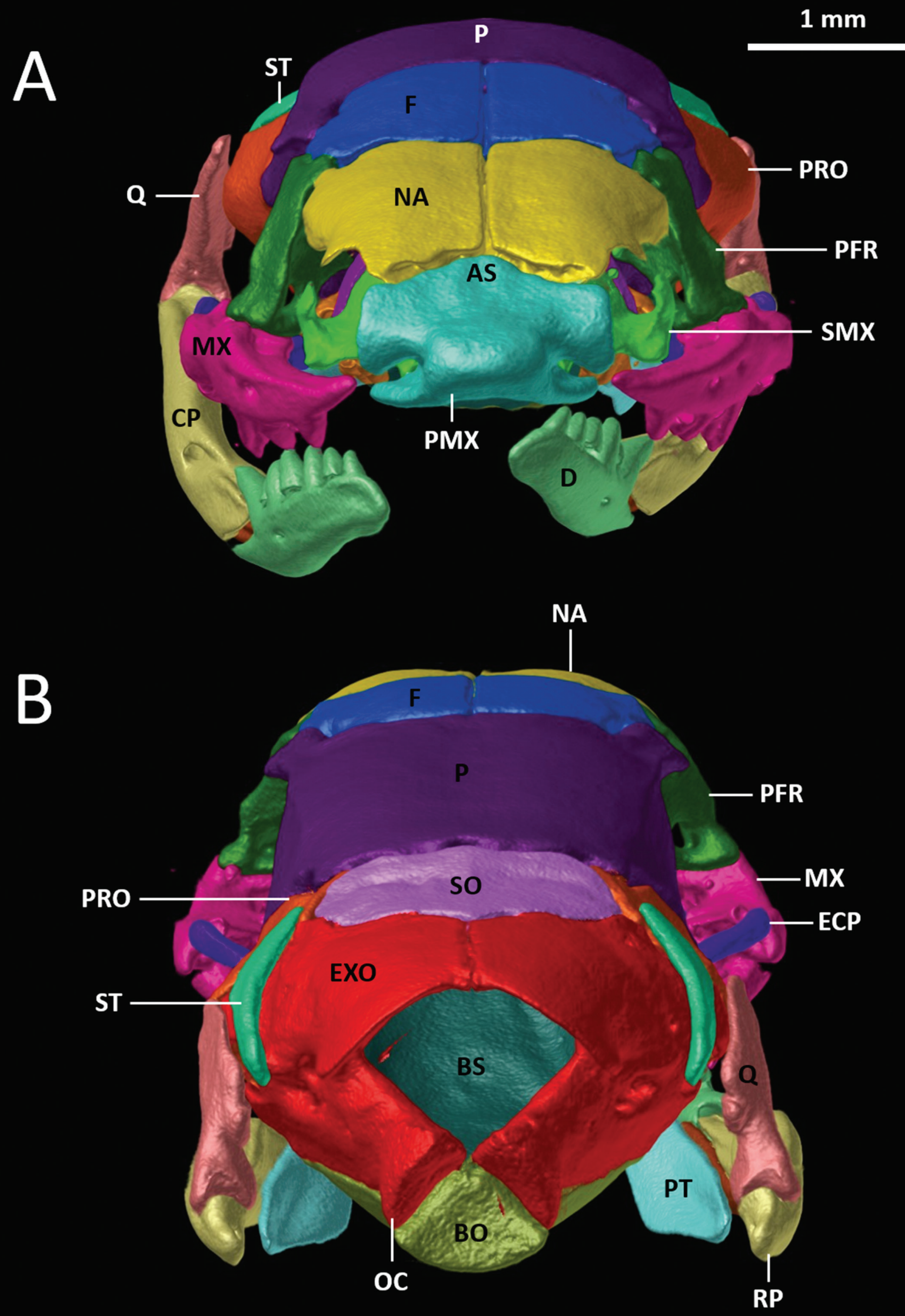

Figure 10. Micro-CT images of the skull of the holotype of Apostolepis ambiniger (ZMB 6450) in A) anterior, and B) posterior views; AS (ascending process of premaxilla); BO (basioccipital); BS (basisphenoid); CP (compound bone); D (dentary); ECP (ectopterygoid); EXO (exoccipital); F (frontal); MX (maxilla); NA (nasal); OC (occipital condyle); P (parietal); PFR (prefrontal); PMX (premaxilla); PRO (prootic); PT (pterygoid); Q (quadrate); RP (retroarticular process of compound bone); SMX (septomaxilla); SO (supraoccipital); ST (supratemporal); V (vomer). 

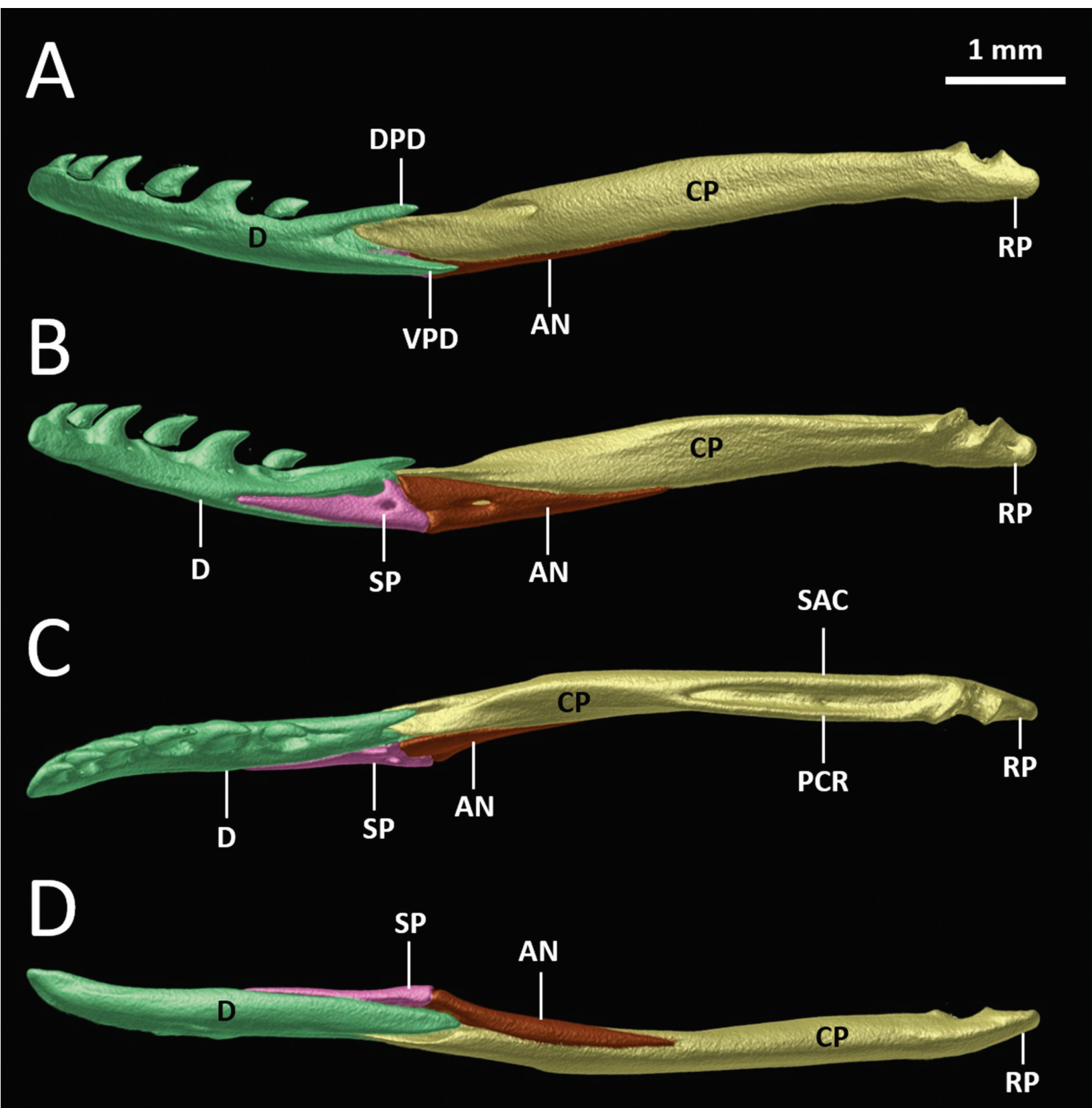

Figure 11. Micro-CT images of the mandible of the holotype of Apostolepis ambiniger (ZMB 6450) in (A) lateral, (B) medial, (C) dorsal, and (D) ventral views; AN (angular); CP (compound bone); D (dentary); DPD (dorsal process of dentary); PCR (prearticular crest of compound bone); RP (retroarticular process of compound bone); SAC (surangular crest of compound bone); SP (splenial); VPD (ventral process of dentary).

ticincta. From Paraguay, A. ambiniger is recorded for the departments of Cordillera, Central, and Presidente Hayes. In light of this evidence, we restrict the occurrence of $A$. ambiniger to Paraguay (Fig. 12; Table 1 in the Supplementary Table).

\section{Discussion}

The identity of Apostolepis ambiniger has been subject to historical controversy. Lema et al. (2005) examined four specimens housed in the Museum für Naturkunde
Berlin (ZMB), among them the holotype ("Holotype?, ZMB 6450" in Lema et al. 2005:36). However, they were not able to pinpoint the holotype perhaps because Peters (1869) did not mention the number of the holotype along the description. One of the authors (TBG), examined the same specimen (ZMB 6450) of Lema et al. (2005) and realized the specimen agrees well with the description of the holotype by Peters (1869), also having the uncommon feature of $1+0$ temporals. Peters (1869) reports the holotype as having 225 ventrals, which is corrected in this work to 219 ventrals and five preventrals.

The documented geographic distribution showed that A. ambiniger seems to be restricted to open areas ecoregions of Humid Chaco and and a small portion in the east 

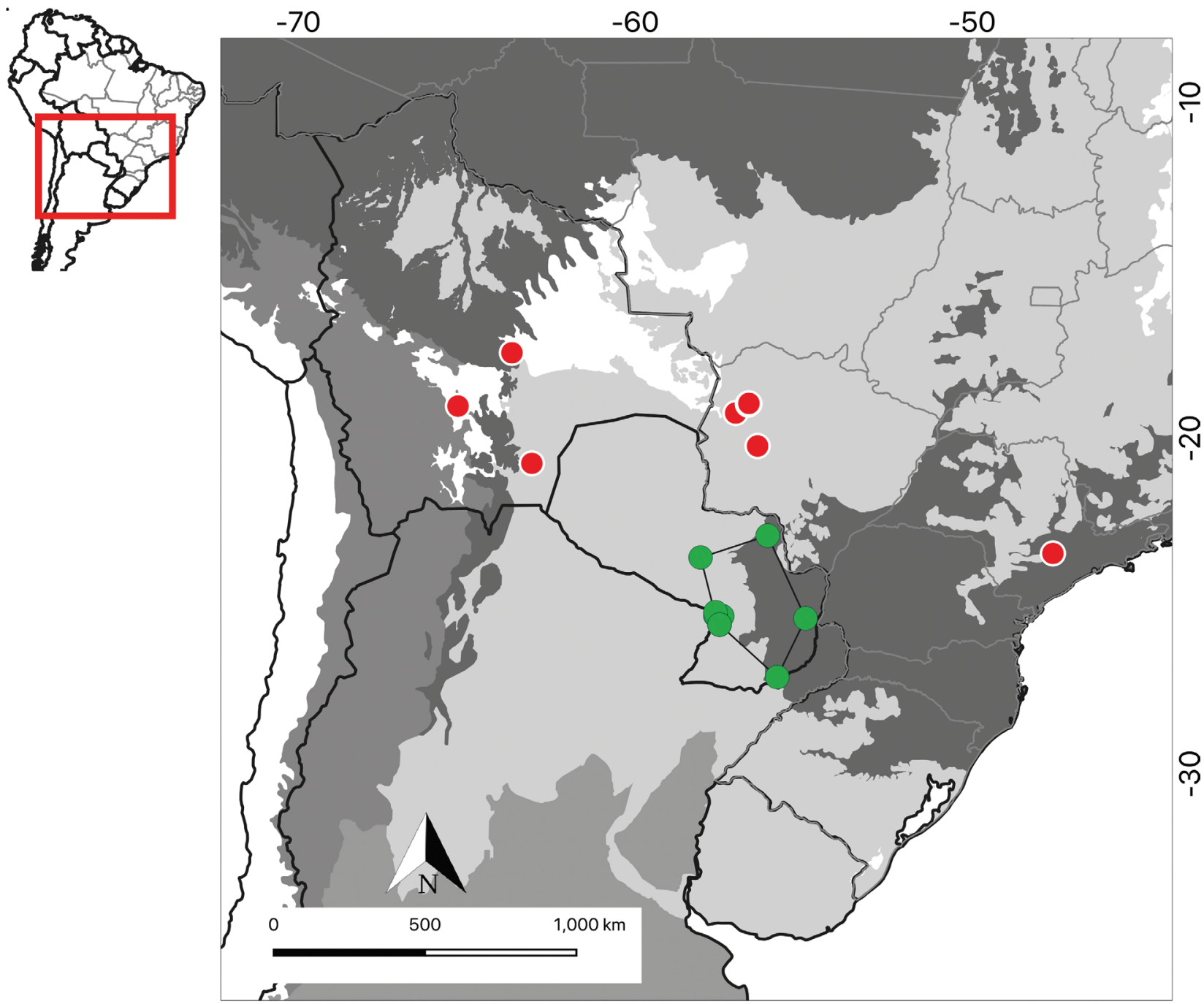

Biomes

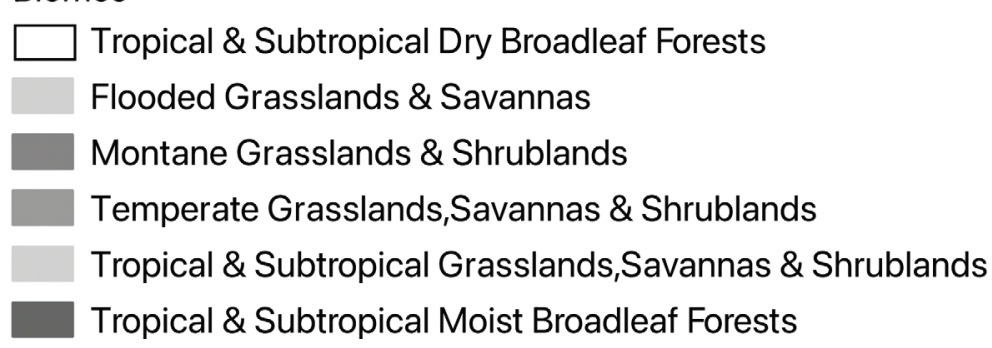

Figure 12. Geographic distribution of $A$. ambiniger. Green circles $=$ verified point records of $A$. ambiniger; red circles $=$ wrong (or from missing specimens) point records previously attributed to $A$. ambiniger (see Table 1 in the Supplementary Table); Polygon = extension of occurrence $\left(7,626.941 \mathrm{~km}^{2}\right)$.

of the Alto Paraná Atlantic Forest (Dinerstein et al. 2017) mostly in Paraguay; previous extralimital records are shown to be cases of misidentifications or mistaken localities. In its geographic distribution, $A$. ambiniger is sympatric with $A$. dimidiata, $A$. intermedia, and possibly with A. assimilis, A. breviceps, A. christineae, A. lineata, A. phillipsi, A. kikoi, and A. vittata. Both A. ambiniger and $A$. dimidiata are morphologically similar, with substantial overlap in diagnostic characters (ventrals, subcaudals, supralabials, infralabials, temporals, nasal-preocular contact, number of infralabials contacting chinshields) which has contributed to misidentifications and taxonomic instability of both species; Apostolepis dimidiata presents a remarkably wide morphological variation, that still needs to be formally assessed (see Entiauspe-Neto et al. 2019). It should be noted that some of the specimens of A. dimidiata mentioned by Lema (1993) and Cabral et al. (2017) have been redetermined as other species [e.g., Apostolepis albicollaris by Nogueira et al. (2012); Elapomorphus quinquelineatus by Costa and Bérnils (2018)], and therefore, literature data should be interpreted with caution. Both species also share very similar hemipenes, with moderately long organs, covered by spinules in apical and medial surfaces, with papillate calyces on sulcate and lateral sides, differing only in characters associated with the shape of the sulcus spermaticus, and distinctive- 
ness of the hemipenial lobes. These characters are also seen in A. albicollaris, A. kikoi and A. goiasensis, species that inhabit open areas in western and central Brazil in sympatry with $A$. dimidiata and not far from the geographic distribution of $A$. ambiniger. The hemipenes of these species are different from the ones seen in $A$. arenaria, A. assimilis, A. cearensis, A. christineae, A. gaboi, A. intermedia, A. longicaudata, A. sanctaeritae, and $A$. quinquelineata, which share small, unilobed or slightly bilobed organs, with spinules or spines on the sulcate side, and lamellae on the asulcate apex (this last character is absent in A. intermedia and A. longicaudata), and from A. flavotorquata, A. nigrolineata, and A. thalesdelemai, which have long, unilobed organs with conspicuous calyculate flounces on their sulcate and asulcate surfaces. As argued by Zaher (1999), hemipenial morphology is highly relevant for systematics, and further studies on these characters are largely warranted for incorporation under a phylogenetic framework in Apostolepis.

The skull of $A$. ambiniger conspicuously differs from congeners, yet skulls have been previously described only for $A$. assimilis, $A$. cearensis, $A$. sanctaeritae. The absence of pterygoid teeth may be unique among its congeners, and possibly constitutes an autapomorphy for A. ambiniger, although this requires further comparisons among its congeners. Its distinctive morphology was highlighted by Peters (1869), who erected the monotypic genus Rhynchonyx for this species. The edentelous pterygoid is also seen in other cryptozoic or fossorial snakes (e.g., Atractaspis irregularis, Rhinophis melanogaster), and might constitute a recurrent and important adaptation for fossoriality (Cundall and Rossmann, 1993). Further integrative work, combining morphological and molecular data, are needed in order to evaluate the phylogenetic position of A. ambiniger, and clarify the systematic relationships of this exquisite taxon to its congeners.

\section{Acknowledgments}

We are deeply indebted to Uwe Fritz (Editor), Gunther Köhler, Uri García-Vázquez, and an anonymous reviewer, who kindly reviewed and provided constructive criticism to our work. OME-N thanks CNPQ for a PIBIC grant (136628/2016-8). We thank Arthur Tiutenko (Arthur Tiutenko Nature Images) for illustrating a specimen of Apostolepis ambiniger in life and hemipenis. We also thank Frank Tillack (ZMB) and Nicolás Martinez for photographing and loaning specimens under their care, and Weverton Azevedo for helping us in the preparation of the plates. TBG thanks the Universidade Estadual do Maranhão for her Senior Researcher fellowship and Fundação de Amparo à Pesquisa do Estado de São Paulo (FAPESP, 2013/04170-8 and 2014/18837-7) for the postdoctoral fellowship that allowed examination of the type specimen at the Museum für Naturkunde Berlin (ZMB).

\section{References}

Amaral AD (1929) Estudos sobre ophidios neotropicos. XVII - Valor systematico de varias formas de ophidios neotropicos. Memórias do Instituto Butantan 4: 3-68.
Boulenger GA (1894) XXXVIII. List of reptiles and batrachians collected by Dr. J. Bohls near Asuncion, Paraguay. The Annals and Magazine of Natural History 13: 342-348.

Boulenger GA (1896) Catalogue of Snakes in the Collection of the British Museum (Natural History). Volume III, containing Colubridae (Opistogliphae and Proterogliphae), Amblycephalidae, and Viperidae. British Museum, London, 818 pp.

Boulenger GA (1898) A list of the reptiles and batrachians collected by the late Prof. L. Balzan in Bolivia. Annali del Museo Civico di Storia Naturale di Genova 39: 128-133.

Bullock RE, Tanner WW (1966) A comparative osteological study of two species of Colubridae (Pituophis and Thamnophis). Brigham Young University Science Bulletin, Biological Series 8: 1-29.

Cabral H, Lema TD, Renner MF (2017) Revalidation of Apostolepis barrioi (Serpentes: Dipsadidae). Phyllomedusa 16: 243-254. https:// doi.org/10.11606/issn.2316-9079.v16i2p243-254

Cope ED (1887) Synopsis of the Batrachia and Reptilia obtained by H. H. Smith in the Province of Mato Grosso, Brazil. Proceedings of the American Philosophical Society 24: 44-60.

Costa HC, Bérnils RS (2018) Répteis do Brasil e suas unidades federativas: lista de espécies. Herpetologia Brasileira 1: 11-48.

Cundall D, Rossman DA (1993) Cephalic anatomy of the rare Indonesian snake Anomochilus weberi. Zoological Journal of the Linnean Society 109: 235-273. https://doi.org/10.1111/j.1096-3642.1993. tb02535.x

Cundall D, Irish F (2008) The snake skull. In: Gans C, Gaunt AS, Adler K (Eds) Biology of Reptilia. The Skull of Lepidosauria. Society for the Study of Amphibian and Reptiles Press, USA, 349-692.

Dixon JR, Hendricks FS (1979) The wormsnakes (Family Typhlopidae) of the Neotropics, exclusive of the Antilles. Zoologische Verhandelingen 173: 1-37.

Dowling HG (1951) A proposed standard system of counting ventrals in snakes. British Journal of Herpetology 1: 97-99.

Entiauspe-Neto OM, de Sena A, Tiutenko A, Loebmann D (2019) Taxonomic status of Apostolepis barrioi Lema, 1978, with comments on the taxonomic instability of Apostolepis Cope, 1862 (Serpentes, Dipsadidae). Zookeys 841: 71-78. http://doi.org/10.3897/zookeys.841.33404

Entiauspe-Neto OM, Koch C, Guedes TB, Tiutenko A (2020a) Revisiting the taxonomic status of Apostolepis sanctaeritae, a forgotten Neotropical dipsadid snake. Salamandra 56: 329-341.

Entiauspe-Neto OM, Guedes TB, Loebmann D, Lema T (2020b) Taxonomic status of two simultaneously described Apostolepis Cope, 1862 species (Dipsadidae: Elapomorphini) from Caatinga enclaves moist forests, Brazil. Journal of Herpetology 54: 225-234. https:// doi.org/10.1670/19-053

Entiauspe-Neto OM, Rangel GMF, Guedes TB, Tiutenko A (2020c) Raising of Lazarus: Rediscovery and redescription of Apostolepis niceforoi Amaral, 1935 (Serpentes: Dipsadidae: Elapomorphini). Holotipus 1: 21-35.

Entiauspe-Neto OM, Koch C, Gray RJ, Tiutenko A, Loebmann D, Guedes TB (2021) On the identity of Apostolepis tertulianobeui Lema, 2004 and integrative revision of Apostolepis assimilis (Reinhardt, 1861) (Serpentes: Dipsadidae). Zoologischer Anzeiger 291: 123-138. https://doi.org/10.1016/j.jcz.2021.01.004

Ferrarezzi H (1993) Sistemática filogenética de Elapomorphus, Phalotris e Apostolepis (Serpentes, Colubridae, Xenodontinae). $\mathrm{PhD}$ dissertation, Universidade de São Paulo, Brazil.

Ferrarezzi H (1994) Uma sinopse dos gêneros e classificação das serpentes (Squamata): II. Família Colubridae. In: Nascimento LB, Ber- 
nardes AT, Cotta GA (Eds) Herpetologia no Brasil 1. PUCMG, Belo Horizonte, 81-91.

Ferrarezzi H, Barbo FE, Albuquerque CE (2005) Phylogenetic relationships of a new species of Apostolepis from Brazilian cerrado, with notes on the assimilis group (Serpentes: Colubridae: Xenodontinae: Elapomorphini). Papéis Avulsos de Zoologia 45: 215-229. http:// doi.org/10.1590/S0031-10492005001600001

Hammer O, Harper DAT, Ryan PD (2001) PAST: Paleontological Statistics Software Package for Education and Data Analysis. Palaentologia Electronica 4: 1-9.

Hartweg N (1932) The status of Apostolepis tenuis Ruthven. Copeia 1932: 103-104.

Harvey MB (1999) Revision of Bolivian Apostolepis (Squamata: Colubridae). Copeia 1999: 388-409. https://doi.org/10.2307/1447485

Harvey MB. Gonzales AL, Scrocchi GJ (2001) New Species of Apostolepis (Squamata: Colubridae) from the Gran Chaco in Southern Bolivia. Copeia 2001: 501-507. https://doi.org/10.1643/0045-8511(2001)001[0501:NSOASC]2.0.CO;2

International Commission of Zoological Nomenclature (1999) International code of zoological nomenclature [the Code]. Fourth edition. The International Trust for Zoological Nomenclature, UK.

Koslowsky J (1898) Ofidios de Matto-Grosso (Brasil). Revista del Museo de La Plata 8: 25-32.

Lema T de (1993) Polimorfismo em Apostolepis dimidiata (Jan, 1862) com a invalidação de Apostolepis villaricae Lema, 1878 e Apostolepis barrioi Lema, 1878 (Serpentes: Colubridae: Xenodontinae: Elapomorphini). Acta Biologica Leopoldensia 15: 35-52.

Lema T de (2001) Fossorial snake genus Apostolepis from South America (Serpentes: Colubridae: Elapomorphinae). Cuadernos de Herpetología 15: 29-43.

Lema T de, Hofstadler-Deiques C (2010) Description of a new genus for allocation of Elapomorpus lepidus and the status of Elapomorphus wuchereri (Serpentes: Dipsadidae: Xenodontinae: Elapomorphini). Neotropical Biology and Conservation 5: 113-119. https:// doi.org/10.4013/4756

Lema T de, Renner MF, Nascimento-Silva C (2005) Contribution to the knowledge of Apostolepis ambiniger (Peters, 1869) (Serpentes: Elapomorphinae). Comunicações do Museu de Ciência e Tecnologia, PUCRS, Série Zoologia 18: 21-36.

McDowell SB (1986) The architecture of the corner of the mouth of colubroid snakes. Journal of Herpetology 20: 353-407. https://doi. org $10.2307 / 1564502$

Nogueira CN, Barbo FE, Ferrarezzi H (2012) Redescription of Apostolepis albicollaris Lema, 2002, with a key for the species groups of the genus Apostolepis (Serpentes: Dipsadidae: Elapomorphini). South American Journal of Herpetology 7: 213-225. http://doi. br/10.2994/057.007.0303
Nogueira CC, Argôlo AJS, Arzamendia V, Azevedo JA, Barbo FE, Bérnils RS, Bolochio BE, Borges-Martins M, Brasil-Godinho M, Braz H, Buononato MA, Cisneros-Heredia DF, Colli GR, Costa HC, Franco FL, Giraudo A, Gonzales RC, Guedes T, Hoogmoed MS, Marques OAV, Montingelli GG, Passos P, Prudente ALC, Rivas GA, Sanchez PM, Serrano FC, Silva-Jr NJ, Strüssmann C, Vieira-Alencar JPS, Zaher H, Sawaya RJ, Martins M (2019) Atlas of Brazilian snakes: Verified point-locality maps to mitigate the Wallacean shortfall in a megadiverse snake fauna. South American Journal of Herpetology 14: 1-274. http://dx.doi.br/10.2994/SAJH-D-19-00120.1

Peracca MG (1895) Viaggio del dott. Alfredo Borelli nella Repubblica Argentina e nel Paraguay. Bollettino dei Musei di Zoologia ed Anatomia Comparata della R. Università di Torino 10: 1-32.

Peters W (1869) Über neue Gattungen und neue oder weniger bekannte Arten von Amphibien (Eremias, Dicrodon, Euprepes, Lygosoma, Typhlops, Eryx, Rhynchonyx, Elapomorphus, Achalinus, Coronella, Dromicus, Xenopholis, Anoplodipsas, Spilotes, Tropidonotus). Monatsberichte der Königlich Preussischen Akademie der Wissenschaften zu Berlin 1869: 432-447.

Peters JA, Orejas-Miranda B (1970) Catalogue of the Neotropical Squamata. Part I. Smithsonian Institution Press, USA, 347pp.

Peters JA, Orejas-Miranda B (1972) The taxonomic validity of Apostolepis tenuis Ruthven and Apostolepis vittata (Cope) (Serpentes: Colubridae). Copeia 1972: 588-590. https://doi.org/10.2307/1442938

QGIS Development Team (2018) Quantum GIS Geographic Information System. Version 2.18. Available at: http://www.qgis.org.

Sabaj MH (2019) Standard Symbolic Codes for Institutional Resource Collections in Herpetology and Ichthyology: An Online Reference. Version 6.5. Available at http://www.asih.org. Accessed on 10 September 2020. American Society of Ichthyologists and Herpetologists, USA.

Savitzky AH (1979) The origin of the New World proteroglyphous snakes and its bearing on the study of venom delivery systems in snakes. PhD dissertation, University of Kansas, USA.

Zaher H (1994) Phylogenie des pseudoboini et evolution des Xenodontinae sud-americains (Serpentes, Colubridae). PhD dissertation, Musée National D'Histoire Naturelle, France.

Zaher H (1999) Hemipenial morphology of the South American xenodontine snakes, with a proposal for a monophyletic Xenodontinae and a reappraisal of colubroid hemipenes. Bulletin of the American Museum of Natural History 240: 1-168.

Zaher H, Grazziotin FG, Cadle JE, Murphy RW, Moura-Leite JCD, Bonatto SL (2009) Molecular phylogeny of advanced snakes (Serpentes, Caenophidia) with an emphasis on South American Xenodontines: a revised classification and descriptions of new taxa. Papéis Avulsos de Zoologia 49: 115-153. http://doi.org/10.1590/ S0031-10492009001100001

\section{Appendix I}

\section{Material examined}

Coordinates are given in SIRGAS2000.

Apostolepis aff. niceforoi $(n=1)$. BRAZIL: Roraima: Caracaraí, Vila de Caicubi, Rio Jufari, $1.797409^{\circ} \mathrm{S}, 61.143789^{\circ} \mathrm{W}$ (MZUSP 19625).
Apostolepis albicollaris $(n=2)$. BRAZIL: Distrito Federal: Brasília, $15.775247^{\circ} \mathrm{S}, 47.922950^{\circ} \mathrm{W}$ (USNM 148789, 148790).

Apostolepis arenaria $(n=5)$. BRAZIL: Bahia: Originally given as "Alagoado", herein corrected to Casa Nova municipality, 9.161121 ${ }^{\circ} \mathrm{S}$, $40.983073^{\circ} \mathrm{W}$ (MZUSP 10027, 10028, 10029, 10030, 10289). 
Apostolepis assimilis $(n=144)$. BRAZIL: Bahia: Barreiras, $12.143650^{\circ} \mathrm{S}, \quad 45.003059^{\circ} \mathrm{W}$ (UMMZ 20411); Distrito Federal: Brasília, $15.775247^{\circ} \mathrm{S}, 47.922950^{\circ} \mathrm{W}$ (CHUNB 24456, 24474, IBSP 20566, 28734, USNM 148790); Goiás: border with Tocantins, Ilha do Bananal, Santa Isabel, $11.080152^{\circ} \mathrm{S}, 50.636316^{\circ} \mathrm{W}$ (IBSP 12324); Jataí, $17.899968^{\circ} \mathrm{S}, 51.730803^{\circ} \mathrm{W}$ (MZUSP 3783 ); Mineiros, $17.558692^{\circ} \mathrm{S}, 52.552554^{\circ} \mathrm{W}$ (IBSP 55495); Rio Verde, $17.787982^{\circ} \mathrm{S}$, $50.937775^{\circ} \mathrm{W}$ (IBSP 10326, 12945, MZUSP 3194), Uruaçu, Cana Brava, $14.519870^{\circ} \mathrm{S}, 49.150580^{\circ} \mathrm{W}$ (IBSP 9154); Minas Gerais: Cabo Verde, $21.475110^{\circ} \mathrm{S}, 46.397057^{\circ} \mathrm{W}$ (IBSP 29448); Cambuí, $22.614916^{\circ} \mathrm{S}, 46.056915^{\circ} \mathrm{W}$ (IBSP 44222), Capão dos Porcos, Mariana, $20.365709^{\circ} \mathrm{S}, 43.407326^{\circ} \mathrm{W}$ (ZMUC 63806, holotype of Apostolepis assimilis), Caxambu, $21.98007^{\circ} \mathrm{S}, 44.932633^{\circ} \mathrm{W}$ (IBSP 816), Conceição dos Ouros, $22.412537^{\circ} \mathrm{S}, 45.800055^{\circ} \mathrm{W}$ (IBSP 33206), Entre Rios de Minas, $20.680355^{\circ} \mathrm{S}, 44.089915^{\circ} \mathrm{W}$ (FUNED 691), Gonçalves, $22.658901^{\circ} \mathrm{S}, 45.856063^{\circ} \mathrm{W}$ (IBSP 49666), Ibirité, $20.012663^{\circ} \mathrm{S}$, $44.081203^{\circ} \mathrm{W}$ (FUNED 603), Itajubá, $22.434017^{\circ} \mathrm{S}, 45.467651^{\circ} \mathrm{W}$ (IBSP 9115, 9407, 9592), Itamonte, $22.284305^{\circ} \mathrm{S}, 44.874096^{\circ} \mathrm{W}$ (IBSP 22405), Itatiaiuçu, 20.204767 ${ }^{\circ} \mathrm{S}, 44.462560^{\circ} \mathrm{W}$ (FUNED 510), Jaíba, $15.345628^{\circ} \mathrm{S}, 43.686232^{\circ} \mathrm{W}$ (FUNED 1465), Maria da Fé, $22.307992^{\circ} \mathrm{S}, 45.378278^{\circ} \mathrm{W}$ (IBSP 5597), Moeda, $20.330538^{\circ} \mathrm{S}$, $44.055868^{\circ} \mathrm{W}$ (FUNED 02), Nova Lima, $20.004714^{\circ} \mathrm{S}, 43.871471^{\circ} \mathrm{W}$ (FUNED 550), Ouro Fino, $22.278276^{\circ} \mathrm{S}, 46.374551^{\circ} \mathrm{W}$ (IBSP 34306), Munhoz, $22.278276^{\circ} \mathrm{S}, 46.374551^{\circ} \mathrm{W}$ (IBSP 66376), Passa Quatro, $22.389193^{\circ} \mathrm{S}, 44.972256^{\circ} \mathrm{W}$ (IBSP 3264, 3274, 34306), Poços de Caldas, $21.812489^{\circ} \mathrm{S}, 46.588499^{\circ} \mathrm{W}$ (IBSP $45737,23985,14256$ ), Pouso Alegre, $22.246732^{\circ} \mathrm{S}, 45.927618^{\circ} \mathrm{W}$ (IBSP $42162,44597,49942$ ), Santa Rosa da Serra, $19.530423^{\circ} \mathrm{S}, 45.967855^{\circ} \mathrm{W}$ (IBSP 46088), Serra do Cipó, $19.370279^{\circ} \mathrm{S}, 43.585560^{\circ} \mathrm{W}$ (MZUSP 7595), Uberabinha, border with São Paulo, $20.016022^{\circ} \mathrm{S}, 47.793120^{\circ} \mathrm{W}$ (IBSP 888), Uberlândia, $19.133733^{\circ} \mathrm{S}, 48.333231^{\circ} \mathrm{W}$ (IBSP 3841, 3845, 6388, 3841), Vespasiano, $19.734960^{\circ} \mathrm{S}, 43.939672^{\circ} \mathrm{W}$ (FUNED 04); Mato Grosso do Sul: Amambaí, $23.111955^{\circ} \mathrm{S}, 55.230187^{\circ} \mathrm{W}$ (IBSP 41163), Campo Grande, $20.494551^{\circ} \mathrm{S}, 54.610826^{\circ} \mathrm{W}$ (IBSP 41163, 42978, 57222, MHNCI 6719 , MZUSP 10155), Nova Andradina, $22.002500^{\circ} \mathrm{S}, 53.491960^{\circ} \mathrm{W}$ (IBSP 27489, 27489), Paranaíba, $19.671986^{\circ} \mathrm{S}, 51.191663^{\circ} \mathrm{W}$ (IBSP 45615), Ponta Porã, $22.512971^{\circ} \mathrm{S}, 55.713606^{\circ} \mathrm{W}$ (IBSP 44065); Mato Grosso: Buriti, $17.973681^{\circ} \mathrm{S}, 53.554398^{\circ} \mathrm{W}$ (IBSP 5346), Cuiabá, $15.426759^{\circ} \mathrm{S}, \quad 55.943251^{\circ} \mathrm{W}$ (MNRJ 2031); Paraná: Londrina, $23.322525^{\circ} \mathrm{S}, 51.176065^{\circ} \mathrm{W}$ (IBSP 37462, 40008); Santa Catarina: Florianópolis (BGSS5344, Locality possibly in error, see Entiauspe-Neto et al. 2020d); São Paulo: Araçariguama, $23.441586^{\circ} \mathrm{S}, 47.069288^{\circ} \mathrm{W}$ (IBSP 83132), Barueri, $23.515768^{\circ} \mathrm{S}, 46.882181^{\circ} \mathrm{W}$ (IBSP 23206), Bauru, $22.327818^{\circ} \mathrm{S}, 49.107726^{\circ} \mathrm{W}$ (MHNCI 4790), Cabreúva, $23.316678^{\circ} \mathrm{S}, 47.082624^{\circ} \mathrm{W}$ (IBSP 26565), Caieiras, $23.374820^{\circ} \mathrm{S}$, $46.735134^{\circ} \mathrm{W}$ (IBSP 40320), Caixa d'Água, coordinates unknown (IBSP 6659), Carapicuíba, $23.540539^{\circ} \mathrm{S}, 46.846607^{\circ} \mathrm{W}$ (IBSP 87769 , 82260 ), Cajamar, $23.348228^{\circ} \mathrm{S}, 46.877875^{\circ} \mathrm{W}$ (IBSP 30408,87083 , 3186), Campo Largo, $25.463235^{\circ} \mathrm{S}, 49.537514^{\circ} \mathrm{W}$ (IBSP 4498), Campo Limpo, $23.635070^{\circ} \mathrm{S}, 46.754990^{\circ} \mathrm{W}$ (IBSP 6532), Campos do Jordão, $22.735380^{\circ} \mathrm{S}, 45.583899^{\circ} \mathrm{W}$ (IBSP 26796, UMMZ 204112), Carapicuíba, $23.54919^{\circ} \mathrm{S}, 46.84454795918558^{\circ} \mathrm{W}$ (IBSP 72970), Cotia, $23.636020^{\circ} \mathrm{S}, 46.956576^{\circ} \mathrm{W}$ (IBSP 24588), Ibiúna, 23.662839 ${ }^{\circ} \mathrm{S}$, $47.213951^{\circ} \mathrm{W}$ (IBSP $32672,79312,78900$ ), Itapevi, 23.554159 ${ }^{\circ} \mathrm{S}$, $46.978074^{\circ} \mathrm{W}$ (IBSP 30436, 86908, 79489), Itatiba, $22.993786^{\circ} \mathrm{S}$, $46.824113^{\circ} \mathrm{W}$ (IBSP 5703), Itu, $23.297557^{\circ} \mathrm{S}, 47.301031^{\circ} \mathrm{W}$ (IBSP 4180, 6606, 82230, , MHNCI 6969, MZUSP 4180, 6606), Jaguara, $23.512151^{\circ} \mathrm{S}, 46.742029^{\circ} \mathrm{W}$ (IBSP 70356 ), Jandira, $23.543093^{\circ} \mathrm{S}$, $46.900625^{\circ} \mathrm{W}$ (IBSP 31694,40493 ), Jarinu, $23.116928^{\circ} \mathrm{S}, 46.716730^{\circ} \mathrm{W}$ (IBSP 30019), Jundiaí, $23.203436^{\circ} \mathrm{S}, 46.939945^{\circ} \mathrm{W}$ (IBSP 16688),
Mairinque, $23.539455^{\circ} \mathrm{S}, 47.185860^{\circ} \mathrm{W}$ (IBSP 41065,89049 ), Osasco, $23.540895^{\circ} \mathrm{S}, 46.795779^{\circ} \mathrm{W}$ (IBSP 23889, 40480, 6141, 62362, 78442, MCP 64), Pirituba, $23.474910^{\circ} \mathrm{S}, 46.743881^{\circ} \mathrm{W}$ (IBSP 70351, 78948), Rio Grande, coordinates unknown (IBSP 40008), Santana de Parnaíba, $23.457582^{\circ} \mathrm{S}, 46.918621^{\circ} \mathrm{W}$ (IBSP 61761, 81066,), São Caetano do Sul, $23.626138^{\circ} \mathrm{S}, 46.565080^{\circ} \mathrm{W}$ (IBSP 81238 ), São Paulo, $23.534933^{\circ} \mathrm{S}$, $46.609078^{\circ} \mathrm{W}$ (IBSP 318, 348, 6401, 6558, 8040, 8945, 21993, 22221, 24180, 24548, 24873, 27598, 30153, 30586, 31716, 32441, $33316,84949,78948$ ), São Roque, $23.528545^{\circ} \mathrm{S}, 47.141170^{\circ} \mathrm{W}$ (IBSP 23548, 78641, , 79658, MHNCI 4495, 6970), Sorocaba, 23.481770 $\mathrm{S}$, 47.455341 ${ }^{\circ} \mathrm{W}$ (IBSP 15760,40008$)$; PARAGUAY: Trinidad: Unknown locality (MZUM 108810).

Apostolepis ambiniger $(n=20)$. PARAGUAY: Unknown locality (ZMB 6450, holotype of Rhynchonyx ambiniger, MNRJ 760, 761, 762, NMW 13807, USNM 73458), Amambay: Pedro Juan Caballero, $22.556997^{\circ} \mathrm{S}$, $55.727736^{\circ} \mathrm{W}$ (MCZ 47002), Cordillera: “Bei” (En: “in”) Altos, 25.264344 ${ }^{\circ} \mathrm{S}, 57.254242^{\circ} \mathrm{W}$ (NMW 20721), Departamento Central: Unknown locality (MVZ 110991), Areguá, $25.303760^{\circ} \mathrm{S}, 57.411182^{\circ} \mathrm{W}$ (MHNP 5163), Asuncíon, $25.272547^{\circ} \mathrm{S}, 57.584233^{\circ} \mathrm{W}$ (ZMB 28729, BMNH 1930.11.27.228, 1834.3.14.70, 1834.3.14.71, 1834.3.14.72, 1834.3.14.73, SMF 20340), Villa Hayes, Asuncíon, 25.272550 $\mathrm{S}$, $57.584240^{\circ} \mathrm{W}$ (ZMB 32144), San Lorenzo, $25.353124^{\circ} \mathrm{S}, 57.505877^{\circ} \mathrm{W}$ (MHNP 3493), Trinidad, $27.128686^{\circ} \mathrm{S}, 55.706528^{\circ} \mathrm{W}$ (UMMZ 108809); Presidente Hayes: Chacoí, 25.248977 $\mathrm{S}, 57.645968^{\circ} \mathrm{W}$ (ZMB 32144).

Apostolepis cearensis $(n=140)$. BRAZIL: Alagoas: Piranhas, $9.607967^{\circ} \mathrm{S}, 37.768092^{\circ} \mathrm{W}$ (CHUFS 3217, 3365, MUFAL 1315); Bahia: Brumado, $14.207125^{\circ} \mathrm{S}, 41.675605^{\circ} \mathrm{W}$ (IBSP 33651, 33685), Camaçari, $12.706750^{\circ} \mathrm{S}, 38.331172^{\circ} \mathrm{W}$ (MZUEFS 371), Capim Grosso, $11.381030^{\circ} \mathrm{S}, 40.010385^{\circ} \mathrm{W}$ (MZUEFS 294), Feira de Santana, $12.223937^{\circ} \mathrm{S}, 38.990827^{\circ} \mathrm{W}$ (MZUEFS 12, 19, 70, 71, 74, 86, 130, $162,166,203,277,310,315,429,434,463,464,505,515,615,624$, $637,669,672,689,771,804,836,841,895,927,1007,1040,1053$, 1067, 1069, 1070, 1071, 1077, 1080, 1110, 1146, 1157, 1158, 1195, 1196, 1208, 1209, 1210, 1236, 1240, 1241, 1244, 1260, 1302, 1310, 1313, 1369, 1377, 1405, 1445, 1446, 1477, 1478, 1479, 1499, 1539, 1559, 1570, 1587, 1604, 1611, 1622, 1629, 1645, 1673, 1674), Poções, $14.526737^{\circ} \mathrm{S}, 40.366499^{\circ} \mathrm{W}$ (MZUFBA 1595, 1796, 1805, 1813, 1826, 1827), São Gonçalo dos Campos, $12.435848^{\circ} \mathrm{S}, 38.952627^{\circ} \mathrm{W}$ (MZUEFS 73,825 ), Jaguarari, $10.258500^{\circ} \mathrm{S}, 40.194672^{\circ} \mathrm{W}$ (IBSP 26203); Ceará: Aquiraz, $3.910332^{\circ} \mathrm{S}, 38.383874^{\circ} \mathrm{W}$ (CHUFC 1185), Beberibe, $4.183106^{\circ} \mathrm{S}, 38.131271^{\circ} \mathrm{W}$ (CHUFC 1628), Crateús, $5.174963^{\circ} \mathrm{S}$, $40.675624^{\circ} \mathrm{W}$ (CHUFC 2238), Crato, $7.244635^{\circ} \mathrm{S}, 39.448914^{\circ} \mathrm{W}$ (IBSP 20385), Fortaleza, $3.76337^{\circ} \mathrm{S}, 38.527876^{\circ} \mathrm{W}$ (CHUFC 208, $826,1240,1242,1243,1524,1525,1526,1527,1528,1529,1531$, $1539,1620,1621,1622,1623,1623,1624,1625,1626,1627,1629$, 2001, 2236, 2287, 2243, 2633, IBSP 20020, 40262, 55318, 18219, 18220), Icó, $6.400202^{\circ} \mathrm{S}, 38.860449^{\circ} \mathrm{W}$ (IBSP 12106), Juazeiro do Norte, $7.228342^{\circ} \mathrm{S}, 39.314310^{\circ} \mathrm{W}$ (IBSP 20164), Limoeiro do Norte, $5.140528^{\circ} \mathrm{S}, 38.071232^{\circ} \mathrm{W}$ (IBSP 12775 ), Maranguape, $3.889587^{\circ} \mathrm{S}$, $38.678660^{\circ} \mathrm{W}$ (CHUFC 2235), Quixadá, $4.969875^{\circ} \mathrm{S}, 39.017092^{\circ} \mathrm{W}$ (CHUFC 1221), São Benedito, $4.045633^{\circ} \mathrm{S}, 40.865595^{\circ} \mathrm{W}$ (CHUFC 2114, 2147), Tianguá, $3.727411^{\circ} \mathrm{S}, 40.997394^{\circ} \mathrm{W}$ (IBSP 77109), Ubajara, $3.865421^{\circ} \mathrm{S}, 40.980188^{\circ} \mathrm{W}$ (IBSP 75855,77101 ), Viçosa do Ceará, $3.566272^{\circ} \mathrm{S}, 41.110413^{\circ} \mathrm{W}$ (IBSP 77509 ); Paraíba: Cabaceiras, $7.490668^{\circ} \mathrm{S}, 36.288036^{\circ} \mathrm{W}$ (MZUSP 9013), Campina Grande, $7.230571^{\circ} \mathrm{S}, 35.892641^{\circ} \mathrm{W}$ (IBSP 9050), Lagoa de Dentro, $6.673537^{\circ} \mathrm{S}$, $35.377482^{\circ} \mathrm{W}$ (MNRJ 17055); Piauí: Teresina, $5.052687^{\circ} \mathrm{S}$, 
$42.764437^{\circ} \mathrm{W}$ (IBSP 49743 ), Redenção do Gurguéia, $9.488261^{\circ} \mathrm{S}$, $44.583311^{\circ} \mathrm{W}$ (IBSP 80942$)$.

Apostolepis cerradoensis $(n=1)$. BRAZIL: Goiás: Minaçu, Cana Brava UHE, $13.510069^{\circ} \mathrm{S}, 48.209950^{\circ} \mathrm{W}$ (MCP 15219 , holotype of Apostolepis cerradoensis).

Apostolepis christineae $(n=2)$. BOLIVIA: Santa Cruz: Puerto Suarez, German Busch, $18.970739^{\circ} \mathrm{S}, 57.816239^{\circ} \mathrm{W}$ (BMNH 1907.10.31.62). BRAZIL: Mato Grosso: Cáceres, $16.076427^{\circ} \mathrm{S}, 57.675286^{\circ} \mathrm{W}$ (MCP 12515, holotype of Apostolepis christineae).

Apostolepis dimidiata $(n=12)$. BRAZIL: Mato Grosso: Unknown locality (AMNH 62192); São Paulo: Unknown locality (AMNH 7245, 102252, FMNH 69934, MCZ 27661, USNM 76369, 76370, ZUEC 936, 2277, 0884, 947).

Apostolepis dorbignyi $(n=2)$. "AMÉRIQUE MÉRIDIONALE": Unknown locality (MNHN 3664, holotype of Apostolepis dorbignyi), BOLIVIA: Tarija (MZUT 963).

Apostolepis flavotorquata $(n=5)$. BRAZIL: Bahia:Unknown locality (UMMZ 108808); Mato Grosso: Unknown locality (AMNH 93559, 935690, 93561, SMS voucher unavailable).

Apostolepis gaboi $(n=34)$. BRAZIL: Bahia: Ibiraba, Barra, $10.787131^{\circ} \mathrm{S}$, $42.823709^{\circ} \mathrm{W}$ (MZUFBA 1673, 1674, 1675, 1676, 1677, 1678, 1679, $1680,1681,1682,1683,1684,1685,1686,1687,1688,1689,1690$, $1691,1692,1693,1694,1695,1696,1697,1698,1699,1700,1701$, $1702,1702,1704$ ), Icatú-Barra, $10.787140^{\circ} \mathrm{S}, 42.823790^{\circ} \mathrm{W}$ (MZUEFS 981), Queimadas, $11.042418^{\circ} \mathrm{S}, 39.699621^{\circ} \mathrm{W}$ (MZUSP 10290).

Apostolepis goiasensis $(n=1)$. BRAZIL: Minas Gerais: Três Lagoas, $20.788371^{\circ} \mathrm{S}, 51.706916^{\circ} \mathrm{W}$ (CHFURG 1344).

Apostolepis intermedia $(n=2)$. PARAGUAY: San Pedro: Laguna Blanca, $23.808604^{\circ} \mathrm{S}, 56.283731^{\circ} \mathrm{W}$ (MHNP 11533, 11636).

Apostolepis kikoi $(n=5)$. BRAZIL: Mato Grosso: APM Manso, Chapada dos Guimarães, $15.090012^{\circ} \mathrm{S}, 55.712671^{\circ} \mathrm{W}$ (MCP 12096, holotype of Apostolepis kikoi, 14524, 14525, 11372, UFMTR 1933, paratypes of Apostolepis kikoi).

Apostolepis longicaudata $(n=1)$. BRAZIL: Tocantins: Estação Ecológica Serra Geral, $10.856603^{\circ} \mathrm{S}, 46.696670^{\circ} \mathrm{W}$ (MZUSP 14122).

Apostolepis lineata $(n=1)$. BRAZIL: Mato Grosso: Chapada dos Guimarães, $15.090012^{\circ} \mathrm{S}, 55.712671^{\circ} \mathrm{W}$ (ANSP 11211, syntype of Apostolepis lineata).

Apostolepis multicincta $(n=5)$. BOLIVIA: Santa Cruz: San Juan, $20.900597^{\circ} \mathrm{S}, 67.765903^{\circ} \mathrm{W}$ (ZFMK 66375, paratype of Apostolepis multicincta), Florida, $19.450080^{\circ} \mathrm{S}, 65.450257^{\circ} \mathrm{W}$ (ZFMK 75025 , 75026), Santa Cruz, $17.792752^{\circ} \mathrm{S}, 63.162745^{\circ} \mathrm{W}$ (MNKR 729, holotype of Apostolepis multicincta, 878, paratype of Apostolepis multicincta).

Apostolepis nelsonjorgei $(n=2)$. BRAZIL: Goiás: Campinaçu, $13.787851^{\circ} \mathrm{S}, 48.571293^{\circ} \mathrm{W}$ (MZUSP 20636); Tocantins: Estação Ecológica Serra Geral, $10.856603^{\circ} \mathrm{S}, 46.696670^{\circ} \mathrm{W}$ (MZUSP 17615).
Apostolepis nigrolineata $(n=217)$. SOUTH AMERICA (ZMB 6447, holotype of Apostolepis nigrolineata). BRAZIL: Unknown locality (BMNH 1946.1.9.82, holotype of Apostolepis pymi), Maranhão: Paruá, BR $316,2.509304^{\circ} \mathrm{S}, 45.785033^{\circ} \mathrm{W}$ (MPEG 10835, 13641, 14352); Maranhão/Pará border: BR 316, km 74, unknown coordinates (MPEG.1064, 1084, 3581, 8192, 10851); Mato Grosso: Paranaita, $9.673178^{\circ} \mathrm{S}, 56.473624^{\circ} \mathrm{W}$ (MZUSP 22344); Pará: Acará, $1.954775^{\circ} \mathrm{S}$, $48.198985^{\circ} \mathrm{W}$ (MPEG 10939), Ananindeua, $1.363090^{\circ} \mathrm{S}, 48.383168^{\circ} \mathrm{W}$ (MPEG 6943, 9459), Apeú, $1.300842^{\circ} \mathrm{S}, 47.988234^{\circ} \mathrm{W}$ (MPEG 586, 587, 696, 1174, 1476, 1479, 2657, 2666, 3331, 3332, 3334, 3335, 5718, 6916, 6919, MCP 11317), Augusto Correa, $1.096654^{\circ} \mathrm{S}, 46.524358^{\circ} \mathrm{W}$ (MPEG 3905, 3954, 5399, 6712, 6713, 6721, 6724, 6737, 8999, 9937, $10764,12450,13074$ ), Baião, $2.791305^{\circ} \mathrm{S}, 49.669744^{\circ} \mathrm{W}$ (MPEG 1596 , 16001605, 18911897, 2101, 2422, 2423, 2560, 2822, 2826, 28642866, $3386,3387,3389,3390,3448,3949,3950,3951,4086,4094,4801,4802$, 4807, 4808, 4811, 48134817, 4828, 4858, 8187), Belém, $1.255141^{\circ} \mathrm{S}$, $48.457572^{\circ} \mathrm{W}$ (IBSP 3033, 3034, 54152; KU 127256, 127257, 140153 , 140154, MPEG 12769, 12770, 12771), Benevides, Genipaula Road, Pratinha, $1.363915^{\circ} \mathrm{S}, 48.253507^{\circ} \mathrm{W}$ (MPEG 7570, 8399, 8615, 8631, $12575,14285,15476)$, Cachoeira do Piriá, $1.760485^{\circ} \mathrm{S}, 46.546425^{\circ} \mathrm{W}$ (MPEG 2174, 2970, 5160, 7821, 7827, 9546, 9558, 9818, 9829, 11486, 11488, 11933, 11937, 12882, 12883, 15060, 15063, 15863), Castanhal, $1.289674^{\circ} \mathrm{S}, 47.932947^{\circ} \mathrm{W}$ (MPEG 5878, 7163, 7173, 10912, 10913, $11794,12693)$, Gurupá, $1.000374^{\circ} \mathrm{S}, 51.464640^{\circ} \mathrm{W}$ (MPEG 16324), IgarapéAçu, $1.137108^{\circ} \mathrm{S}, 47.619212^{\circ} \mathrm{W}$ (MPEG 868, 869, 870, 871, 910, 912, 913, 924, 925), Inhangabi, $1.431096^{\circ} \mathrm{S}, 47.910219^{\circ} \mathrm{W}$ (MPEG $1464,1568,1571$ ), Marabá, $5.345396^{\circ} \mathrm{S}, 49.118178^{\circ} \mathrm{W}$ (MPEG 17304), Ilha de Outeiro, $1.259871^{\circ} \mathrm{S}, 48.445750^{\circ} \mathrm{W}$ (MCP 10718), Ourém, $1.551101^{\circ} \mathrm{S}, 47.117504^{\circ} \mathrm{W}$ (MPEG 4224, 5004, 5005, 5012, 7016, 7019), Santa Bárbara do Pará, $1.189924^{\circ} \mathrm{S}, 48.257630^{\circ} \mathrm{W}$ (MPEG 1855 , 2608, 3952), Santarém, $2.445930^{\circ} \mathrm{S}, 54.730186^{\circ} \mathrm{W}$ (MPEG 8011), Santarém Novo, $0.908698^{\circ} \mathrm{S}, 47.348546^{\circ} \mathrm{W}$ (MPEG 1841, 1977, 3251, $4154,4796,7081$ ), Santo Antônio do Tauá, $1.081319^{\circ} \mathrm{S}, 48.161660^{\circ} \mathrm{W}$ (MPEG 1000, 1453, 1872, 1873, 1879, 2375, 2376, 2643, 3306, 3940, 3940, 4718, 4720, 4721, 4723, 4730, 6958, 7557), Serra dos Carajás, $6.277626^{\circ} \mathrm{S}, 50.581624^{\circ} \mathrm{W}$ (MZUFV 1071), Serra de Kukoinhokren (herein inferred as Ourilandia do Norte), $6.753257^{\circ} \mathrm{S}, 51.0794844^{\circ} \mathrm{W}$ (MZUSP 1068485 ), Uruá, $4.544668^{\circ} \mathrm{S}, 56.311443^{\circ} \mathrm{W}$ (IBSP 7285 , MZUSP 7287), Utinga, unknown coordinates (KU 128094), Viseu, $1.575437^{\circ} \mathrm{S}, 46.570213^{\circ} \mathrm{W}$ (MPEG 1735, 1787, 2292, 2293, 2323, 2349,314243 3714, 3953, 4458, 5239, 5249, 5320, 5321, 5324, 5325, 5327, 5329, 6633, 7291, 7325, 7338, 7701, 8959, 10010, 10884, 10886, 10887, 11267, 11268, 13260, 15126, 15127, 17279); Rondônia: Machadinho do Oeste, $9.349686^{\circ} \mathrm{S}, 61.981843^{\circ} \mathrm{W}$ (MZUSP 21888); Mato Grosso:Pontes e Lacerda, $15.232549^{\circ} \mathrm{S}, 59.333494^{\circ} \mathrm{W}$ (MPEG 2500).

Apostolepis quinquelineata $(n=4)$. GUYANA: Georgetown, 6.797002 ${ }^{\circ} \mathrm{S}, 58.156512^{\circ} \mathrm{W}$ (BMNH 89.9.30.12, holotype of Apostolepis quinquelineata). BRAZIL: Amazonas: Presidente Figueiredo, $2.031079^{\circ} \mathrm{S}, 60.025275^{\circ} \mathrm{W}$ (INPAH 31440 ); Rondônia: Porto Velho, $8.758575^{\circ} \mathrm{S}, 63.883062^{\circ} \mathrm{W}$ (UFROH 228, 229).

Apostolepis niceforoi $(n=1)$. COLOMBIA: Caquetá: Florencia, $1.614836^{\circ} \mathrm{S}, 75.608047^{\circ} \mathrm{W}(\mathrm{ICN} 10422)$.

Apostolepis nigroterminata $(n=13)$. BOLIVIA: Unknown locality (USNM 280371); Santa Cruz: Unknown locality (BMNH 1927.8.1.180, 1927.8.1.181, 1927.8.1.182, CM 2909, MNKR 472, 942, UMMZ 60773, 67962, 67963, UTA 44687); BRAZIL: Mato Grosso: Comodoro, $13.657177^{\circ} \mathrm{S}, 59.795470^{\circ} \mathrm{W}$ (MPEG 26500), Vila Bela da Santíssima 
Trindade, $15.005081^{\circ} \mathrm{S}, 59.948396^{\circ} \mathrm{W}$ (MZUSP 6408); PERU: Cayaria (herein considered as Pucallpa), $8.360497^{\circ} \mathrm{S}, 74.585841^{\circ} \mathrm{W}(\mathrm{BMNH}$ 1946.1.9.77, holotype)

Apostolepis quirogai $(n=1)$. BRAZIL: Rio Grande do Sul: Santo Ângelo, Campus URI, $28.277008^{\circ} \mathrm{S}, 54.270656^{\circ} \mathrm{W}$ (MCP 12185).

Apostolepis sanctaeritae $(n=31)$. BRAZIL: Bahia: Unknown locality (MCP 8442), Cocos, $14.181859^{\circ} \mathrm{S}, 44.537064^{\circ} \mathrm{W}$ (IBSP 61525, CHUNB 51360, CHUNB 23715), Correntina, $13.571514^{\circ} \mathrm{S}, 45.303100^{\circ} \mathrm{W}$ (CHUNB 39079), Santa Rita de Cássia, Ibipetuba, $10.866069^{\circ} \mathrm{S}$, $44.610886^{\circ} \mathrm{W}$ (NMW 23452, holotype of Apostolepis sanctaeritae, MZUFBA 728, topotype); Distrito Federal: Brasília, $15.775247^{\circ} \mathrm{S}$, 47.922950 W (IBSP 49363); Goiás: Unknown locality (IBSP 15723); Minaçu, $13.510069^{\circ} \mathrm{S}, 48.209950^{\circ} \mathrm{W}$ (IBSP 40478), São Domingos, $13.401192^{\circ} \mathrm{S}, 46.322214^{\circ} \mathrm{W}$ (IBSP 62593, IBSP 67392); Mato Grosso: Nova Xavantina, $14.662802^{\circ} \mathrm{S}, 52.362981^{\circ} \mathrm{W}$ (MCP 8002), Ribeirão Cascalheira, $12.939072^{\circ} \mathrm{S}, 51.828372^{\circ} \mathrm{W}$ (MCP 19481), São Félix do Araguaia, $11.617427^{\circ} \mathrm{S}, 50.666608^{\circ} \mathrm{W}$ (IBSP 15723); Minas Gerais: Betim, $19.925915^{\circ} \mathrm{S}, 44.222527^{\circ} \mathrm{W}$ (FUNED 03), Curvelo, $18.762770^{\circ} \mathrm{S}$, $44.440999^{\circ} \mathrm{W}$ (IBSP 22410 ), Pirapora, $17.353695^{\circ} \mathrm{S}, 44.889140^{\circ} \mathrm{W}$ (MPEG 18347), Serra do Cipó, $19.370279^{\circ} \mathrm{S}, 43.585560^{\circ} \mathrm{W}$ (MZUSP 7595); Três Marias, $18.218011^{\circ} \mathrm{S}, 45.239204^{\circ} \mathrm{W}$ (FUNED, Without voucher); Vazante, $17.989087^{\circ} \mathrm{S}, 46.899214^{\circ} \mathrm{W}$ (IBSP 48041); Tocantins: Gurupi, $11.729458^{\circ} \mathrm{S}, 49.074318^{\circ} \mathrm{W}$ (MZUSP 8007); Lajeado, $9.839862^{\circ} \mathrm{S}, 48.321855^{\circ} \mathrm{W}$ (IBSP 64533, IBSP 64534, IBSP 65571,
IBSP 65680, IBSP 65681), Palmas, $10.283001^{\circ} \mathrm{S}, 48.342440^{\circ} \mathrm{W}$ (IBSP 65267, holotype of Apostolepis ammodites), Porto Nacional, $10.683005^{\circ} \mathrm{S}, 48.377269^{\circ} \mathrm{W}$ (IBSP 65682, IBSP 65683, IBSP 66166), Santa Isabel, $11.384446^{\circ} \mathrm{S}, 48.073970^{\circ} \mathrm{W}$ (IBSP 12324).

Apostolepis tenuis $(n=2)$. BOLIVIA: Beni: Guayaramirim, $10.827529^{\circ} \mathrm{S}, 65.363502^{\circ} \mathrm{W}$ (USNM 123973); Santa Cruz: Buena Vista, Ichilo, $16.888852^{\circ} \mathrm{S}, 64.189732^{\circ} \mathrm{W}$ (UMMZ 64436, holotype of Apostolepis tenuis).

Apostolepis thalesdelemai $(n=39)$. BRAZIL: Ceará: Guaramiranga, $4.261648^{\circ} \mathrm{S}, 38.932367^{\circ} \mathrm{W}$ (CHUFC 1950, 2067, 2353, 2371); Ibiapina, $3.925965^{\circ} \mathrm{S}, 40.888903^{\circ} \mathrm{W}$ (CHUFC 2337, 2340, 2342, 2343 , 2351, 2437); Maranguape, $4.008095^{\circ} \mathrm{S}, 38.818735^{\circ} \mathrm{W}$ (CHUFC 2102 , 2208, 2212, 2213, 2218, 2339, 2347, IBSP 80734); Pacoti, $4.226994^{\circ} \mathrm{S}$, $38.921911^{\circ} \mathrm{W}$ (CHUFC 2344, 2346, 2463, 2731, 2841); São Benedito, $4.047003^{\circ} \mathrm{S}, 40.866281^{\circ} \mathrm{W}(\mathrm{CHUFC} 2338)$; Ubajara, $3.859255^{\circ} \mathrm{S}$, 40.926629 ${ }^{\circ} \mathrm{W}$ (CHUFC 1349, 2085, 2110, 2137, 2154, 2341, 2350, 2769, 2954, IBSP 80735, ZUEC 3384).

Apostolepis vittata $(n=4)$. BRAZIL: Mato Grosso: Chapada dos Guimarães, $15.090012^{\circ} \mathrm{S}, 55.712671^{\circ} \mathrm{W}$ (ANSP 11293, holotype of Rhynchonyx ambiniger vittatus; CHUNB 30656), Parque Nacional Chapada dos Guimarães, $15.090012^{\circ} \mathrm{S}, 55.712671^{\circ} \mathrm{W}$ (UFMTR 12259), Rio da Casca, $15.359774^{\circ} \mathrm{S}, 55.458283^{\circ} \mathrm{W}(\mathrm{MCP} 13283)$.

\section{Supplementary material}

\section{File 1}

Authors: Entiauspe-Neto OM, Koch C, Harvey MB, Colli GR, Guedes TB (2021)

Data type: .docx

Explanation note: Supplementary Table 1. Historical records of Apostolepis ambiniger. - Supplementary Figure 1. Micro-CT images of the skull of the holotype of Apostolepis ambiniger (ZMB 6450).

Copyright notice: This dataset is made available under the Open Database License (http://opendatacommons. org/licenses/odbl/1.0). The Open Database License $(\mathrm{ODbL})$ is a license agreement intended to allow users to freely share, modify, and use this Dataset while maintaining this same freedom for others, provided that the original source and author(s) are credited.

Link: https://doi.org/10.3897/vz.71.e65097.supp11 